\title{
COVID-19 outcomes of 10,881 patients: retrospective study of neurological symptoms and associated manifestations (Philippine CORONA Study)
}

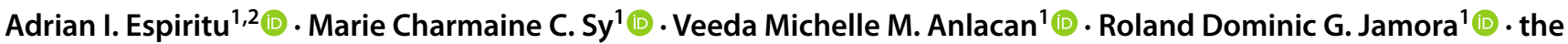 \\ Philippine CORONA Study Group Investigators
}

Received: 28 June 2021 / Accepted: 3 August 2021 / Published online: 27 August 2021

(c) The Author(s) 2021

\begin{abstract}
Our study aimed to determine the effects of new-onset neurological symptoms (NNS) on clinically relevant outcomes in hospitalized patients with COVID-19 infection. We conducted a nationwide, comparative, retrospective, cohort study among adult, hospitalized COVID-19 patients involving 37 hospital sites from various regions in the Philippines. We included a total of 10,881 patients with confirmed COVID-19 infection (2008 had NNS while 8873 did not have NNS). The adjusted hazard ratios (aHRs) for mortality among the mild and severe cases were significantly higher by 1.660 (95\% CI 1.132-2.435) and by 1.352 (95\% CI 1.042-1.752), respectively, in the NNS group compared to those in the non-NNS group. The aHRs for respiratory failure in the NNS group were significantly increased by 1.914 (95\% CI 1.346-2.722), by 1.614 (95\% CI 1.260-2.068), and by 1.234 (95\% CI 1.089-1.398) among the mild, severe, and critical cases, respectively. The aHRs for ICU admission in the NNS group were still significantly higher by 1.973 (95\% CI 1.457-2.673) and by 1.831 (95\% CI 1.506-2.226) among the mild and severe cases, respectively. Patients who had NNS were not significantly associated with a longer duration of ventilator dependence (adjusted odds ratio (aOR) $0.954,95 \%$ CI 0.772-1.179), longer ICU stay (aOR $0.983,95 \%$ CI $0.772-1.252$ ) and longer hospital admission (aOR 1.045, 95\% CI 0.947-1.153). The presence of NNS significantly increases the risk of mortality, respiratory failure and ICU admission among COVID-19 patients. Registration and associated protocol publication: ClinicalTrials.gov website (NCT04386083); Espiritu AI, Sy MCC, Anlacan VMM, Jamora RDG. The Philippine COVID-19 Outcomes: a Retrospective study Of Neurological manifestations and Associated symptoms (The Philippine CORONA study): a protocol study. BMJ Open. 2020;10:e040944.
\end{abstract}

Keywords COVID-19 New-onset neurological symptoms $\cdot$ Mortality $\cdot$ Respiratory failure $\cdot$ Intensive care unit admission Cohort study

Adrian I. Espiritu, MD, and Marie Charmaine C. Sy, MD, MBA, contributed equally to this manuscript.

The members of the Philippine CORONA Study Group Investigators are mentioned in Acknowledgements section.

Adrian I. Espiritu

aiespiritu@up.edu.ph; espirituadrian@gmail.com

1 Division of Adult Neurology, Office of the Department of Neurosciences, College of Medicine and Philippine General Hospital, University of the Philippines Manila, Taft Avenue, Ermita, 1000 Manila, Philippines

2 Department of Clinical Epidemiology, College of Medicine, University of the Philippines Manila, Manila, Philippines

$\begin{array}{ll}\text { Abbreviations } \\ \text { 95\% CI } & \text { 95\% confidence intervals } \\ \text { ARDS } & \text { Acute respiratory distress syndrome } \\ \text { COVID-19 } & \text { Coronavirus disease 2019 } \\ \text { DM } & \text { Diabetes mellitus } \\ \text { DVD } & \text { Duration of ventilator dependence } \\ \text { HPN } & \text { Hypertension } \\ \text { HR } & \text { Hazard ratio } \\ \text { ICU } & \text { Intensive care unit } \\ \text { IQR } & \text { Interquartile range } \\ \text { LHS } & \text { Length of hospital stay } \\ \text { LICUS } & \text { Length of ICU stay } \\ \text { NNS } & \text { New-onset neurological symptoms } \\ \text { OR } & \text { Odds ratio }\end{array}$




RT-PCR $\begin{aligned} & \text { Reverse transcription polymerase chain } \\ & \text { reaction }\end{aligned}$

SARS-CoV-2 Severe acute respiratory syndrome coronavirus 2

\section{Introduction}

The coronavirus disease 2019 (COVID-19) is caused by severe acute respiratory syndrome coronavirus 2 (SARSCoV-2) and has affected over 192 million individuals worldwide as of July 23, 2021 (Coronavirus disease (COVID19) n.d.). During this period in the Philippines, our data breached the 1.5 million mark of confirmed total cases; nearly 54 thousand are active cases and approximately 28 thousand patients died from this infection (Department of Health (Philippines) 2021). Nationwide, about $50 \%$ of the intensive care unit (ICU), isolation, and ward beds were occupied and nearly $40 \%$ of the total mechanical ventilators were used (Department of Health (Philippines) 2021). In July 2021, only 5.5 million individuals, approximately $5 \%$ of the population, were fully vaccinated in the country (Coronavirus (COVID-19) Vaccinations-Statistics and Research-Our World in Data 2021), which is exceedingly distant from the target of about $75-90 \%$ vaccinated individuals to achieve herd immunity from this infection (Anderson et al. 2020). With the recent advent of local transmission of the Delta (B.1.617.2) variant in the country which could potentially initiate a surge and overwhelm our healthcare systems, the Department of Health is currently focusing its attention to implement stricter border control policies and to strengthen local COVID-19 responses (Department of Health (Philippines) 2021).

Current reports of neurological symptoms/signs and complications of this infection are limited due to the small number of included patients and relatively short duration of data collection which could hinder more precise estimates and detection of rarer manifestations (Amanat et al. 2021; Benussi et al. 2020; Chachkhiani et al. 2020; Chuang et al. 2021; Collantes et al. 2021; Flores-Silva et al. 2021). Although there were two powered studies that provided a glimpse on the effects of neurological manifestations on mortality (Eskandar et al. 2021; Frontera et al. 2021), there are no comparative cohort studies yet that explored the effects of new-onset neurological symptoms (NNS) on other clinically relevant outcomes such as respiratory failure, duration of ventilator dependence, admission to the intensive care (ICU) unit and length of ICU and hospital stay. Furthermore, these two large studies were conducted in New York City (NYC) where healthcare systems and outcomes may be remarkably different from low-middle income or developing countries like the Philippines.
Therefore, we aimed to determine the clinical/neurological features of hospitalized patients with COVID-19 infection and to investigate the effects of NNS on mortality, respiratory failure, duration of ventilator dependence, ICU admission, length of ICU and hospital stay among these patients.

\section{Methodology}

\section{Study design}

We performed a nationwide, multicenter, comparative, retrospective, cohort study involving patients with COVID-19 who were admitted to our hospitals/study sites from February 2020 until December 2020. The study's protocol was registered in ClinicalTrials.gov (NCT04386083) and was previously published (Espiritu et al. 2020).

\section{Setting}

The study encompassed a total of 37 major hospitals/study sites from various regions in the Philippines (see the complete list of the sites below).

\section{Patient selection, sampling and cohort description}

We included a total enumeration of all patients that fulfilled the inclusion criteria, as follows: adults $\geq 19$ years of age; confirmed cases via COVID-19 real-time reverse transcription polymerase chain reaction (RT-PCR) of patients' nasopharyngeal swab samples which were performed by testing centers accredited by the Department of Health (Philippines); clinical symptoms/signs ascribed to COVID-19 infection; patients with the appropriate disposition by the end of the data collection period (e.g., discharged, transferred to another hospital, or died). Individuals who were transferred to another hospital were excluded to prevent duplication of data.

Adult COVID-19 patients who had new-onset neurological symptom/s (NNS) were grouped under the exposed cohort while those without NNS (non-NNS) were classified under the unexposed cohort.

\section{Information sources, data collection, patient variables, and bias}

We collected relevant information from the patient medical charts. Pilot-tested electronic collection forms generated using Epi Info Software (Version 7.2.2.16) were employed. The details of the obtained patient variables were indicated in the published protocol (Espiritu et al. 2020). Recording 
bias was considered inherent in this retrospective cohort study.

\section{Outcome variables}

We obtained the following relevant patient outcomes: mortality; respiratory failure (patients with clinical symptoms/signs of respiratory insufficiency (increased work of breathing/tachypnea [respiratory rate of $\geq 22$ ], a necessity to administer supplemental oxygen, or abnormal blood gases [Partial pressure of oxygen $<60$ /hypoxemia or partial pressure of carbon dioxide $>45 /$ hypercapnia])); duration of ventilator dependence (DVD) (days from the start of assisted ventilation to cessation); ICU admission (COVID19 patients admitted to an ICU or ICU-comparable setting; length of ICU stay (LICUS) (days admitted in the ICU); and length of hospital stay (LHS) (days from admission to discharge).

\section{Sample size}

The calculation of the sample size, computed at 1342 patients, was specified in the published protocol (Espiritu et al. 2020).

\section{Statistical analysis}

We summarized demographic, medical, and neurological characteristics using frequencies (\%) for categorical variables and medians (interquartile range, IQR) for continuous variables. We determined distribution differences between two independent samples using Mann-Whitney $U$ and $\chi^{2}$ tests. We employed odds ratios (OR) and hazard ratios (HR) and corresponding $95 \%$ confidence intervals (CI) as the outcome measures for our dichotomous and time-to-event outcomes, respectively. The ORs for longer ventilator dependence, longer ICU stay, and longer hospitals stays were computed via multivariate logistic regression. Data on the time to onset of mortality, respiratory failure, ICU admission were used to build Kaplan-Meier curves; the log-rank test was employed to compare the curves. Confounder and effect modifiers were identified by performing stratified analysis. Adjusted HRs and ORs with 95\% CI were computed based on prespecified confounders/effect modifiers. Significant factors that affect the outcomes were determined using Cox proportional regression models. The final model was further rectified using likelihood ratio tests and other information criteria (Akaike or Bayesian). Goodness-of-fit was assessed via Hosmer-Lemeshow test and Cox-Snell residuals. A $p$ value $<0.05$ (two tailed) was set for all analyses. Statistically significant differences were also detected if the $95 \%$ $\mathrm{CI}$ did not include number one. We conducted all statistical analyses using Stata ${ }^{\circledR}$, Version 7.2.2.16 (College Station, TX: StataCorp LP).

\section{Ethical considerations}

This study was approved by the individual institutional review and research boards of the hospital sites and the Single Joint Research Ethics Board of the Department of Health of the Philippines (see complete list below).

\section{Results}

\section{Inclusion of patients}

We identified 10,999 hospitalized patients diagnosed with COVID-19 (i.e., verified via RT-PCR) from the 37 participating study sites. A total of 10,881 were included in the qualitative and quantitative analyses. Two thousand eight patients were identified with the primary exposure (i.e., NNS group) while the remaining 8873 did not have the exposure (i.e., non-NNS group). Missingness of data for relevant outcomes was considered very minimal; thus, we deemed it unnecessary to explore its effects (see Fig. 1).

\section{Demographic and clinical characteristics of included COVID-19 patients}

The median (IQR) age of the full cohort was 52 (36-64) with a female:male ratio was 1:1.13. A higher proportion of patients with NNS was found among those who are elderly ( $\geq 60$ years) compared to non-elderly (19-59 years) (19.8\% vs. $17.7 \%$; $p=0.007)$. No significant difference in the proportion of patients with NNS was found between females and males (18.7\% vs. $18.35 ; p=0.609)$. The most typical declared exposure to COVID-19 infection was community/ domestic travel $(n=3894,35.8 \%)$. Hypertension (HPN) $(n=3647,33.5 \%)$ and diabetes mellitus (DM) $(n=2191$, $20.1 \%)$ were the most common comorbidities. Most patients had mild $(n=6690,61.5 \%)$ and severe $(n=2354,21.6 \%)$ COVID-19 infection. A considerable proportion of patients received systemic glucocorticoids $(n=2844,26.1 \%)$, remdesivir $(n=1344,12.4 \%)$, and tocilizumab $(n=1029,9.4 \%)$. Other pertinent clinical features and comparison of characteristics of the NNS and non-NNS groups are displayed in Table 1.

\section{Neurological features of included COVID-19 patients}

The most common new-onset neurological symptom was headache ( $n=607,5.58 \%)$, anosmia/hyposmia $(n=544$, $5.0 \%)$, and altered sensorium $(n=479,4.4 \%)$. The proportion of patients who had new-onset neurological 
Fig. 1 Flow of patients in the Philippine CORONA study
10,999 hospitalized patients diagnosed with COVID-19 (i.e., tested positive for COVID-19 reverse transcription polymerase chain reaction)

62 patients were excluded due to age (i.e., $\leq 18$ years of age)

56 patients were excluded because they were transferred to another hospital

10,937 adult, hospitalized, COVID-19 patients

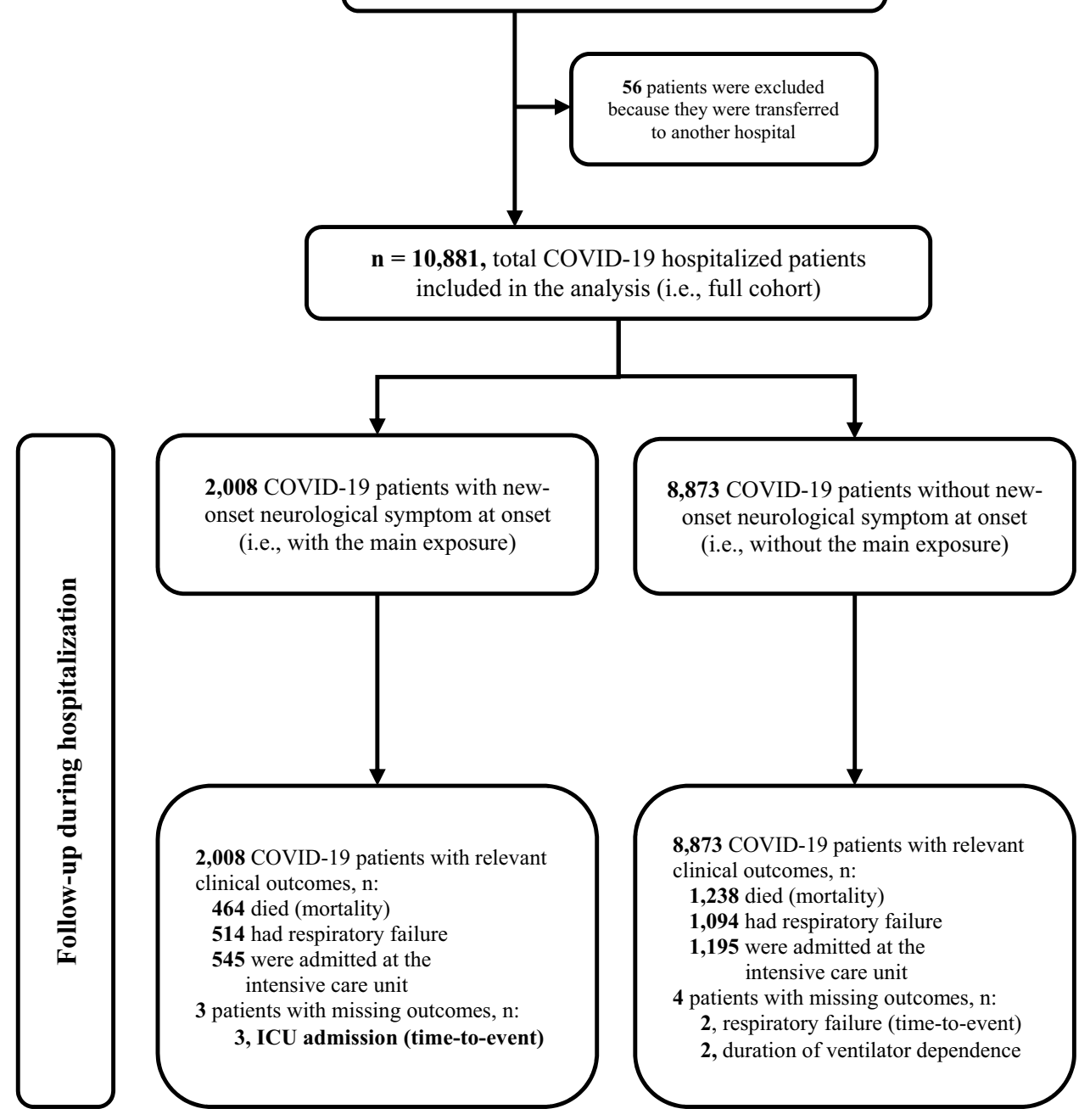

disorder/complication was $8.97 \%(n=976)$; most patients had encephalopathy $(n=622,5.72 \%)$, any acute cerebrovascular disease $(n=367,3.37 \%)$, and any seizure event ( $n=125, n=1.16 \%$ ). Among all the included patients, a number of individuals had a past neurological history of stroke/cerebrovascular diseases $(n=321,2.95 \%)$, dementia $(n=38,0.35 \%)$, and epilepsy $(n=27,0.25 \%)$. Among patients who underwent computed tomography or magnetic resonance imaging $(n=760)$, most lesions were present in the parietal cortex $(n=113,14.9 \%)$, basal ganglia $(n=112,14.7 \%)$, and frontal cortex $(n=95,12.5 \%)$. Very few patients in our cohort underwent cerebrospinal fluid analysis $(n=38)$. A more detailed presentation of neurological characteristics is displayed in Tables 2, 3 . 
Table 1 Demographics and clinical features of patients included in the analysis

\begin{tabular}{|c|c|c|c|c|}
\hline Features & All patients & $\begin{array}{l}\text { COVID-19 patients with } \\
\text { NNS }\end{array}$ & $\begin{array}{l}\text { COVID-19 patients without } \\
\text { NNS }\end{array}$ & $p$ value* \\
\hline Sample, $n(\%)$ & $10,881(100.0)$ & 2008 (18.4) & $8873(81.5)$ & - \\
\hline Age in years, median (IQR) & $52.0(36.0-64.0)$ & $54.0(38.0-65.0)$ & $52.0(35.0-64.0)$ & $<0.001$ \\
\hline \multicolumn{5}{|l|}{ Frequencies of age groups, $n(\%)$} \\
\hline 60 years and above & $3834(35.2)$ & $760(37.8)$ & 3074 (34.6) & \multirow[t]{2}{*}{0.007} \\
\hline $19-59$ years & $7047(64.8)$ & $1248(62.2)$ & $5799(65.4)$ & \\
\hline \multicolumn{5}{|l|}{ Sex, $n(\%)$} \\
\hline Female & $5099(46.9)$ & $951(47.4)$ & $4148(46.7)$ & \multirow[t]{2}{*}{0.609} \\
\hline Male & $5780(53.1)$ & $1056(52.6)$ & $4724(53.2)$ & \\
\hline \multicolumn{5}{|l|}{ Nationality, $n(\%)$} \\
\hline Filipino & $10,789(99.2)$ & $1996(99.4)$ & $8793(99.1)$ & \multirow[t]{2}{*}{0.179} \\
\hline Others & $92(0.8)$ & $12(0.6)$ & $80(0.9)$ & \\
\hline \multicolumn{5}{|l|}{ History of COVID-19 exposure, $n(\%)$} \\
\hline International travel & $323(3.0)$ & $42(2.1)$ & $281(3.2)$ & \multirow[t]{3}{*}{$<0.001$} \\
\hline Community/domestic travel & $3894(35.8)$ & $871(43.4)$ & $3023(34.1)$ & \\
\hline Hospital & $1362(12.5)$ & $266(13.2)$ & $1096(12.4)$ & \\
\hline \multicolumn{5}{|l|}{ Comorbidities, $n(\%)$} \\
\hline Hypertension & $3647(33.5)$ & $927(46.2)$ & $2720(30.6)$ & $<0.001$ \\
\hline Diabetes mellitus & $2191(20.1)$ & $523(26.0)$ & $1668(18.8)$ & $<0.001$ \\
\hline Kidney disease & $611(5.6)$ & $174(8.7)$ & $437(4.9)$ & $<0.001$ \\
\hline Bronchial asthma & $463(4.2)$ & $105(5.2)$ & $358(4.0)$ & 0.017 \\
\hline Coronary artery disease & $421(3.9)$ & $100(5.0)$ & $321(3.6)$ & 0.004 \\
\hline Malignancy & $244(2.2)$ & $70(3.5)$ & $174(2.0)$ & $<0.001$ \\
\hline Chronic obstructive pulmonary disease & $156(1.4)$ & $24(1.2)$ & $132(1.5)$ & 0.32 \\
\hline Heart failure & $127(1.2)$ & $44(2.2)$ & $83(0.9)$ & $<0.001$ \\
\hline Liver disease & $60(0.6)$ & $17(0.8)$ & $43(0.5)$ & 0.048 \\
\hline Human immunodeficiency virus infection & $37(0.3)$ & $9(0.4)$ & $28(0.3)$ & 0.357 \\
\hline Smoker, $n(\%)$ & $1026(9.4)$ & $278(13.8)$ & $748(8.4)$ & $<0.001$ \\
\hline Healthcare worker, $n(\%)$ & $876(8.0)$ & $235(11.7)$ & $641(7.2)$ & $<0.001$ \\
\hline Pregnant, $n(\%)$ & $323(3.0)$ & $28(1.4)$ & $295(3.3)$ & $<0.001$ \\
\hline \multicolumn{5}{|l|}{ Respiratory and constitutional symptoms, $n(\%)$} \\
\hline Cough & $4411(40.5)$ & 995 (49.6) & $3416(38.5)$ & $<0.001$ \\
\hline Fever & $3927(36.1)$ & $886(44.1)$ & $3041(34.3)$ & $<0.001$ \\
\hline Dyspnea & $2703(24.8)$ & $613(30.5)$ & $2090(23.6)$ & $<0.001$ \\
\hline Sore throat & $751(6.9)$ & $211(10.5)$ & $540(6.1)$ & $<0.001$ \\
\hline Fatigue & $713(6.6)$ & $220(11.0)$ & $493(5.6)$ & $<0.001$ \\
\hline Sputum production & $637(5.8)$ & $194(9.7)$ & $443(5.0)$ & $<0.001$ \\
\hline Rhinorrhea & $607(5.6)$ & $200(10.0)$ & 407 (4.6) & $<0.001$ \\
\hline Diarrhea & $597(5.5)$ & $163(8.1)$ & $434(4.9)$ & $<0.001$ \\
\hline Arthralgia & $175(1.6)$ & $45(2.2)$ & $130(1.5)$ & 0.013 \\
\hline Hemoptysis & $33(0.3)$ & $6(0.3)$ & $27(0.3)$ & 0.968 \\
\hline \multicolumn{5}{|l|}{ COVID-19 disease severity, $n(\%)$} \\
\hline Mild & $6690(61.5)$ & $1114(55.5)$ & $5576(62.8)$ & \multirow[t]{3}{*}{$<0.001$} \\
\hline Severe & 2354 (21.6) & $413(20.6)$ & 1941 (21.9) & \\
\hline Critical & $1707(15.7)$ & $468(23.3)$ & $1239(14.0)$ & \\
\hline \multicolumn{5}{|l|}{ Treatment received, $n(\%)$} \\
\hline Systematic glucocorticoids & $2844(26.1)$ & $743(37.0)$ & $2101(23.7)$ & $<0.001$ \\
\hline Remdesivir & $1344(12.4)$ & $325(16.2)$ & $1019(11.5)$ & $<0.001$ \\
\hline Tocilizumab & $1029(9.4)$ & $188(9.4)$ & $841(9.5)$ & 0.873 \\
\hline Lopinavir-Ritonavir & $579 .(5.3)$ & $99(4.9)$ & $480(5.4)$ & 0.387 \\
\hline Hydroxychloroquine & $529(4.9)$ & $116(5.8)$ & $413(4.6)$ & 0.035 \\
\hline Chloroquine & $358(3.3)$ & $68(3.4)$ & $290(3.3)$ & 0.789 \\
\hline Convalescent plasma & $263(2.4)$ & $80(4.0)$ & $183(2.1)$ & $<0.001$ \\
\hline
\end{tabular}

$N N S$ new-onset neurological symptom, IQR interquartile range

*Difference between NNS and non-NNS groups 
Table 2 Past neurological history, and new-onset neurological symptoms and disorders/complications associated with the hospitalized COVID19 patients included in the analysis $(N=10,881)$

\begin{tabular}{|c|c|c|c|c|c|}
\hline Past neurological history & Frequency $(\%)$ & $\begin{array}{l}\text { New-onset neurological } \\
\text { symptoms }\end{array}$ & Frequency $(\%)$ & $\begin{array}{l}\text { New-onset neurological disor- } \\
\text { ders/complications }\end{array}$ & Frequency $(\%)$ \\
\hline $\begin{array}{l}\text { Stroke/cerebrovascular } \\
\text { diseases }\end{array}$ & $321(2.95)$ & Headache & $607(5.58)$ & $\begin{array}{l}\text { Any neurological disorder/ } \\
\text { complication }\end{array}$ & $976(8.97)$ \\
\hline Dementia & $3(0.35)$ & Anosmia/hyposmia & $544(5.00)$ & Encephalopathy & $622(5.72)$ \\
\hline Epilepsy & $27(0.25)$ & Altered sensorium & $479(4.40)$ & $\begin{array}{l}\text { Any acute cerebrovascular } \\
\text { disease }\end{array}$ & $367(3.37)$ \\
\hline Neuropathy & $9(0.08)$ & Ageusia/dysgeusia & $338(3.11)$ & $\begin{array}{l}\text { Acute cerebrovascular } \\
\text { infarction }\end{array}$ & $262(2.41)$ \\
\hline Movement disorder & $6(0.06)$ & Myalgia & $256(2.35)$ & $\begin{array}{l}\text { Acute cerebrovascular hem- } \\
\text { orrhagic stroke }\end{array}$ & $101(0.93)$ \\
\hline Headache syndrome & $5(0.04)$ & Extremity weakness & $246(2.26)$ & Any seizure disorder & $125(1.16)$ \\
\hline $\begin{array}{l}\text { Central nervous system infec- } \\
\text { tion }\end{array}$ & $5(0.04)$ & Dizziness & $159(1.46)$ & Acute symptomatic seizure & $63(0.58)$ \\
\hline $\begin{array}{l}\text { Neuromuscular junction } \\
\text { disorder }\end{array}$ & $5(0.04)$ & Confusion & $143(1.31)$ & Status epilepticus & $19(0.17)$ \\
\hline $\begin{array}{l}\text { Central demyelinating syn- } \\
\text { drome }\end{array}$ & $2(0.02)$ & Vomiting & $126(1.16)$ & Epilepsy & $17(0.16)$ \\
\hline Myelopathy & $2(0.02)$ & Seizure & $96(0.88)$ & Anoxic brain & $51(0.47)$ \\
\hline $\begin{array}{l}\text { Peripheral nervoussystem } \\
\text { infection }\end{array}$ & $3(0.03)$ & Dysarthria & $83(0.76)$ & Any movement disorder & $3(0.03)$ \\
\hline \multirow[t]{18}{*}{ Myopathy } & \multirow[t]{18}{*}{0} & Nausea & $82(0.75)$ & \multicolumn{2}{|l|}{ Inflammatory syndromes } \\
\hline & & $\begin{array}{l}\text { Extremity numbness/pares- } \\
\text { thesia }\end{array}$ & $53(0.49)$ & Meningitis & $13(0.12)$ \\
\hline & & Facial weakness & $40(0.37)$ & Encephalitis & $6(0.06)$ \\
\hline & & Tremor & $25(0.23)$ & Meningoencephalitis & $1(0.01)$ \\
\hline & & Facial numbness/paresthesia & $20(0.18)$ & $\begin{array}{r}\text { Acute disseminated } \\
\text { encephalomyelitis }\end{array}$ & $1(0.01)$ \\
\hline & & Dysphagia & $16(0.15)$ & $\begin{array}{l}\text { Acute necrotizing hemor- } \\
\text { rhagic encephalopathy }\end{array}$ & 0 \\
\hline & & Tongue weakness & $8(0.07)$ & Cerebellitis & 0 \\
\hline & & Blindness/decreased vision & $6(0.06)$ & Cerebellitis & 0 \\
\hline & & Ataxia & $5(0.04)$ & Optic neuritis & $1(0.01)$ \\
\hline & & Meningismus & $5(0.04)$ & Myelitis & 0 \\
\hline & & $\begin{array}{l}\text { Hearing loss/decreased hear- } \\
\text { ing }\end{array}$ & $4(0.04)$ & $\begin{array}{l}\text { Sensory ganglionitis dorsal } \\
\text { radiculitis }\end{array}$ & 0 \\
\hline & & Dysphonia & $4(0.04)$ & $\begin{array}{l}\text { Anterior horn syndrome } \\
\text { polio-like syndrome/ven- } \\
\text { tral radiculitis }\end{array}$ & $2(0.02)$ \\
\hline & & Neck weakness & $3(0.03)$ & $\begin{array}{l}\text { Peripheral neuritis/GBS-like } \\
\text { syndrome }\end{array}$ & $5(0.04)$ \\
\hline & & $\begin{array}{l}\text { Ophthalmoparesis/ophthal- } \\
\text { moplegia }\end{array}$ & $2(0.02)$ & $\begin{array}{l}\text { Peripheral neuritis other } \\
\text { than GBS-like syndrome }\end{array}$ & $1(0.01)$ \\
\hline & & Eye pain & $3(0.03)$ & Myositis & $1(0.01)$ \\
\hline & & Bradykinesia & $3(0.03)$ & Neuromuscular disorder & $3(0.03)$ \\
\hline & & Dystonia & 0 & & \\
\hline & & Choreoathethosis & 0 & & \\
\hline
\end{tabular}

GBS Guillain-Barré syndrome 
Table 3 Summary of findings in COVID-19 patients who underwent computed tomography/magnetic resonance imaging and cerebrospinal fluid (CSF) analysis

\begin{tabular}{|c|c|}
\hline Findings & Frequency $(\%)$ \\
\hline \multicolumn{2}{|l|}{ Radiologic imaging } \\
\hline Number of patients with any radiologic imaging, $n$ & 760 \\
\hline \multicolumn{2}{|c|}{$\begin{array}{l}\text { Number of patients with the affected segment of the central nervous system evi- } \\
\text { denced by radiologic imaging, } n(\%)\end{array}$} \\
\hline Whole brain & $25(3.3)$ \\
\hline Frontal cortex & $95(12.5)$ \\
\hline Temporal cortex & $81(10.6)$ \\
\hline Parietal cortex & $113(14.9)$ \\
\hline Occipital cortex & $46(6.0)$ \\
\hline Subcortical white matter & $90(11.8)$ \\
\hline Basal ganglia & $112(14.7)$ \\
\hline Thalamus & $44(5.8)$ \\
\hline Hypothalamus & $3(0.4)$ \\
\hline Cerebellum & $41(5.4)$ \\
\hline Midbrain & $13(1.7)$ \\
\hline Pons & $38(5.0)$ \\
\hline Medulla & $2(0.3)$ \\
\hline Cervical spinal cord & $3(0.4)$ \\
\hline Thoracic spinal cord & $3(0.4)$ \\
\hline Lumbar spinal cord & $3(0.4)$ \\
\hline Sacral spinal cord & 0 \\
\hline \multicolumn{2}{|l|}{ CSF analysis } \\
\hline Number of patients with CSF analysis, $n$ & 38 \\
\hline Median CSF total cell count (IQR), cells $/ \mu \mathrm{L}$ & $3.0(2.3-14)$ \\
\hline Number of patients with pleocytosis* in the CSF, $n(\%)$ & $6(15.8)$ \\
\hline Median CSF neutrophil count (IQR), cells $/ \mu \mathrm{L}$ & $1(0-8)$ \\
\hline Number of patients with neutrophil/s $\mathrm{s}^{\dagger}$ in the CSF, $n(\%)$ & $8(21.0)$ \\
\hline Median CSF lymphocyte count (IQR), cell/ $\mu \mathrm{L}$ & $13(0-55)$ \\
\hline Number of patients with lymphocytosis* in the CSF, $n(\%)$ & $7(18.4)$ \\
\hline Median CSF protein (IQR), mg/dL & $157.5(37.8-708.0)$ \\
\hline Number of patients with increased protein ${ }^{\ddagger}$ in the CSF, $n(\%)$ & $8(21.0)$ \\
\hline Median CSF glucose (IQR), mg/dL & $7.6(5.2-65.5)$ \\
\hline Median serum glucose (IQR), mg/dL & $126.0(59.9-157.5)$ \\
\hline Number of patients with hypoglycorrhachia ${ }^{\S}, n(\%)$ & $8(21.0)$ \\
\hline
\end{tabular}

$I Q R$ Interquartile range

$*>5$ cells $/ \mu \mathrm{L}$ of $\mathrm{CSF}$

$\dagger \geq 1$ cell $/ \mu \mathrm{L}$ of $\mathrm{CSF}$

${ }^{\ddagger} \mathrm{CSF}$ protein concentration $\geq 60 \mathrm{mg} / \mathrm{dL}$

${ }^{\S} \mathrm{CSF}$ glucose concentration $<2 / 3$ of serum glucose concentration

\section{Effects of new-onset neurological symptom/s on outcomes of included COVID-19 patients and survival analysis}

Table 4 shows the comparison of outcomes between NNS and non-NNS groups among the included COVID19 patients while Table 5 presents the crude and adjusted hazard ratio for mortality, respiratory failure and ICU admission. Figure 2 shows the Kaplan-Meier cumulative hazard functions for NNS and non-NNS groups in terms of mortality, respiratory failure and ICU admission. For all survival analyses, it was found that the effect of NNS on the outcomes was significantly different depending on COVID19 severity.

\section{Mortality}

A total of $1702(15.6 \%)$ died in the full cohort; acute respiratory distress syndrome (ARDS) $(n=749,44.0 \%)$ and septic shock $(n=699,41.1 \%)$ were the typical causes of 
Table 4 Comparison of outcomes in COVID-19 patients with NNS vs. without NNS

\begin{tabular}{|c|c|c|c|c|}
\hline Outcomes & All COVD-19 patients & $\begin{array}{l}\text { COVID-19 patients } \\
\text { with NNS }\end{array}$ & $\begin{array}{l}\text { COVID-19 patients } \\
\text { without NNS }\end{array}$ & $p$ value* \\
\hline \multicolumn{5}{|l|}{ Mortality and associated causes } \\
\hline Mortality, $n(\%)$ & $1702(15.6)$ & $464(23.1)$ & $1238(14.0)$ & $<0.001^{\dagger}$ \\
\hline Acute respiratory distress syndrome & $749(44.0)$ & $216(10.8)$ & $533(6.0)$ & $<0.001^{\dagger}$ \\
\hline Septic shock & $699(41.1)$ & $162(8.1)$ & $537(6.1)$ & $0.001^{\dagger}$ \\
\hline Multi-organ dysfunction syndrome & $150(8.8)$ & $23(1.1)$ & $127(1.4)$ & 0.321 \\
\hline Acute coronary syndrome & $138(8.1)$ & $33(1.6)$ & $105(1.2)$ & 0.096 \\
\hline Cardiac arrhythmia & $106(6.2)$ & $19(0.9)$ & $87(1.0)$ & 0.888 \\
\hline Brain herniation & $66(3.9)$ & $43(2.1)$ & $23(0.3)$ & $<0.001^{\dagger}$ \\
\hline Decompensated heart failure & $44(2.6)$ & $9(0.4)$ & $35(0.4)$ & 0.732 \\
\hline \multicolumn{5}{|l|}{ Respiratory failure and associated causes } \\
\hline Respiratory failure, $n(\%)$ & $1608(14.8)$ & $514(25.6)$ & $1094(12.3)$ & $<0.001^{\dagger}$ \\
\hline Pneumonia & $927(57.6)$ & $324(16.1)$ & $603(6.8)$ & $<0.001^{\dagger}$ \\
\hline Acute respiratory distress syndrome & $868(54.0)$ & $218(10.9)$ & $650(7.3)$ & $<0.001^{\dagger}$ \\
\hline Shock & $147(9.1)$ & $48(2.4)$ & $99(1.1)$ & $<0.001^{\dagger}$ \\
\hline Central neurological cause & $89(5.5)$ & $82(4.1)$ & $7(0.1)$ & $<0.001^{\dagger}$ \\
\hline Pulmonary edema & $33(2.0)$ & $16(0.8)$ & $17(0.2)$ & $<0.001^{\dagger}$ \\
\hline Pulmonary embolism & $21(1.3)$ & $2(0.1)$ & $19(0.2)$ & 0.404 \\
\hline Peripheral neurological cause & $2(0.1)$ & 0 & $2(0.02)$ & 1.000 \\
\hline Pulmonary hemorrhage & $1(0.1)$ & $1(0.05)$ & 0 & 0.185 \\
\hline \multicolumn{5}{|l|}{ Duration of ventilator dependence } \\
\hline \multicolumn{5}{|l|}{ Duration of ventilator dependence } \\
\hline Sample, $n$ & 1606 & 514 & 1092 & 0.612 \\
\hline Median (IQR) & $13(8-20)$ & $13(8-20)$ & $13(8-20)$ & \\
\hline \multicolumn{5}{|l|}{ ICU admission and reasons for admission } \\
\hline ICU admission, $n(\%)$ & $1740(16.0)$ & $545(27.1)$ & $1195(13.5)$ & $<0.001^{\dagger}$ \\
\hline Acute respiratory distress syndrome & $956(54.9)$ & $236(11.8)$ & $720(8.1)$ & $<0.001^{\dagger}$ \\
\hline Shock & $180(10.3)$ & $59(2.9)$ & $121(1.4)$ & $<0.001^{\dagger}$ \\
\hline Impaired level of consciousness & $110(6.3)$ & $85(4.2)$ & $25(0.3)$ & $<0.001^{\dagger}$ \\
\hline Acute myocardial infarction & $80(4.6)$ & $13(0.6)$ & $67(0.8)$ & 0.610 \\
\hline Acute kidney injury necessitating dialysis & $75(4.3)$ & $27(1.3)$ & $48(0.5)$ & $<0.001^{\dagger}$ \\
\hline Treatment-related indication & $71(4.1)$ & $28(1.4)$ & $43(0.5)$ & $<0.001^{\dagger}$ \\
\hline Acute stroke & $57(3.3)$ & $51(2.5)$ & $6(0.1)$ & $<0.001^{\dagger}$ \\
\hline Cardiac arrhythmia & $36(2.1)$ & $6(0.3)$ & $30(0.3)$ & 0.782 \\
\hline Post-cardiac arrest & $23(1.3)$ & $5(0.2)$ & $18(0.2)$ & 0.599 \\
\hline Cerebral edema & $18(1.0)$ & $15(0.7)$ & $3(0.03)$ & $<0.001^{\dagger}$ \\
\hline Venous thromboembolism & $13(0.7)$ & $1(0.05)$ & $12(0.1)$ & 0.484 \\
\hline \multicolumn{5}{|l|}{ Length ICU stay } \\
\hline \multicolumn{5}{|l|}{ Length of ICU stay } \\
\hline Sample, $n$ & 1737 & 545 & 1192 & 0.887 \\
\hline Median (IQR) & $15(9.5-21)$ & $15(10-21)$ & $15(9-21)$ & \\
\hline \multicolumn{5}{|l|}{ Length of hospital stay } \\
\hline \multicolumn{5}{|l|}{ Length of hospital stay } \\
\hline Sample, $n$ & 10,881 & 2008 & 8873 & $0.002^{\dagger}$ \\
\hline Median (IQR) & $13(10-19)$ & $14(10-19)$ & $13(10-19)$ & \\
\hline
\end{tabular}

$I C U$ intensive care unit, $I Q R$ interquartile range, $N N S$ new-onset neurological symptoms

*Difference between NNS and non-NNS groups

${ }^{\dagger}$ Statistically significant (i.e., alpha set at 0.5 ) 
Table 5 Crude and fully adjusted hazard ratio for mortality, ICU admission and respiratory failure comparing patients with NNS vs. patients without NNS

\begin{tabular}{|c|c|c|}
\hline Characteristic & $\mathrm{HR}(95 \% \mathrm{CI})$ & $\begin{array}{l}p \text { value for } \\
\text { association }^{\dagger}\end{array}$ \\
\hline \multicolumn{3}{|l|}{ Mortality } \\
\hline Crude HR for mortality & $1.423(1.278-1.585)$ & - \\
\hline \multicolumn{3}{|l|}{ Fully adjusted HR for mortality } \\
\hline \multicolumn{3}{|l|}{ COVID-19 severity* } \\
\hline Mild & $1.660(1.132-2.434)$ & $0.01^{\ddagger}$ \\
\hline Severe & $1.352(1.042-1.752)$ & $0.023^{\ddagger}$ \\
\hline Critical & $1.043(0.920-1.181)$ & 0.511 \\
\hline \multicolumn{3}{|l|}{ Confounders } \\
\hline Hypertension & $0.863(0.781-0.954)$ & $0.04^{\ddagger}$ \\
\hline Age & $1.010(1.007-1.013)$ & $<0.001^{\ddagger}$ \\
\hline Sex (male) & $0.959(0.870-1.058)$ & 0.405 \\
\hline \multicolumn{3}{|l|}{ Respiratory failure } \\
\hline Crude HR for respiratory failure & $1.857(1.670-2.065)$ & - \\
\hline \multicolumn{3}{|c|}{ Fully adjusted HR for respiratory failure } \\
\hline \multicolumn{3}{|l|}{ COVID-19 severity* } \\
\hline Mild & $1.914(1.346-2.722)$ & $<0.001^{\ddagger}$ \\
\hline Severe & $1.614(1.260-2.068)$ & $<0.001^{\ddagger}$ \\
\hline Critical & $1.234(1.089-1.398)$ & $0.001^{\ddagger}$ \\
\hline \multicolumn{3}{|l|}{ Confounders } \\
\hline Smoker & $1.364(1.889-1.565)$ & 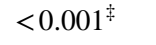 \\
\hline Hypertension & $1.517(1.355-1.699)$ & $<0.001^{*}$ \\
\hline Diabetes mellitus & $1.174(1.055-1.307)$ & $0.003^{\ddagger}$ \\
\hline Age & $0.999(0.996-1.002$ & 0.536 \\
\hline Sex (male) & $0.852(0.768-0.945)$ & $0.003^{\ddagger}$ \\
\hline \multicolumn{3}{|l|}{ ICU admission } \\
\hline Crude HR for ICU admission & $1.802(1.626-1.996)$ & - \\
\hline \multicolumn{3}{|c|}{ Fully adjusted HR for ICU admission } \\
\hline \multicolumn{3}{|c|}{ COVID-19 severity* } \\
\hline Mild & $1.973(1.457-2.673)$ & $<0.001^{\ddagger}$ \\
\hline Severe & $1.831(1.506-2.226)$ & $<0.001^{*}$ \\
\hline Critical & $1.122(0.985-1.279)$ & 0.084 \\
\hline \multicolumn{3}{|l|}{ Confounders } \\
\hline Smoker & $1.443(1.267-1.643)$ & $<0.001^{\ddagger}$ \\
\hline Hypertension & $1.692(1.516-1.889)$ & $<0.001^{\ddagger}$ \\
\hline Diabetes mellitus & $1.268(1.144-1.404)$ & $<0.001^{*}$ \\
\hline Age & $0.999(0.996-1.002)$ & 0.630 \\
\hline Sex (male) & $0.884(0.800-0.977)$ & $0.016^{\ddagger}$ \\
\hline
\end{tabular}

95\% CI 95\% confidence intervals, NNS new-onset neurological symptoms, $H R$ hazard ratio, ICU Intensive care unit

*Interaction term (likelihood ratio test) $p$ value $=0.03$

†Wald's test

${ }^{\ddagger}$ Statistically significant (i.e., alpha set at 0.05 ) mortality. Among those who died, a significantly higher proportion of patients was found in the NNS compared to those in the non-NNS group $(p<0.001)$; among those who died due to ARDS $(p<0.001)$, septic shock $(p=0.001)$, and brain herniation $(p<0.001)$, a statistically higher percentage of patients was found in the NNS group. The crude HR for mortality was significantly higher among those in the NNS group by 1.423 (95\% CI 1.278-1.585) than those in the non-NNS group (see Fig. 2A). After adjusting for age, sex, and presence of HPN, the risk of mortality differed depending on the disease severity. Among the mild and severe cases, the adjusted HRs remained significantly higher by 

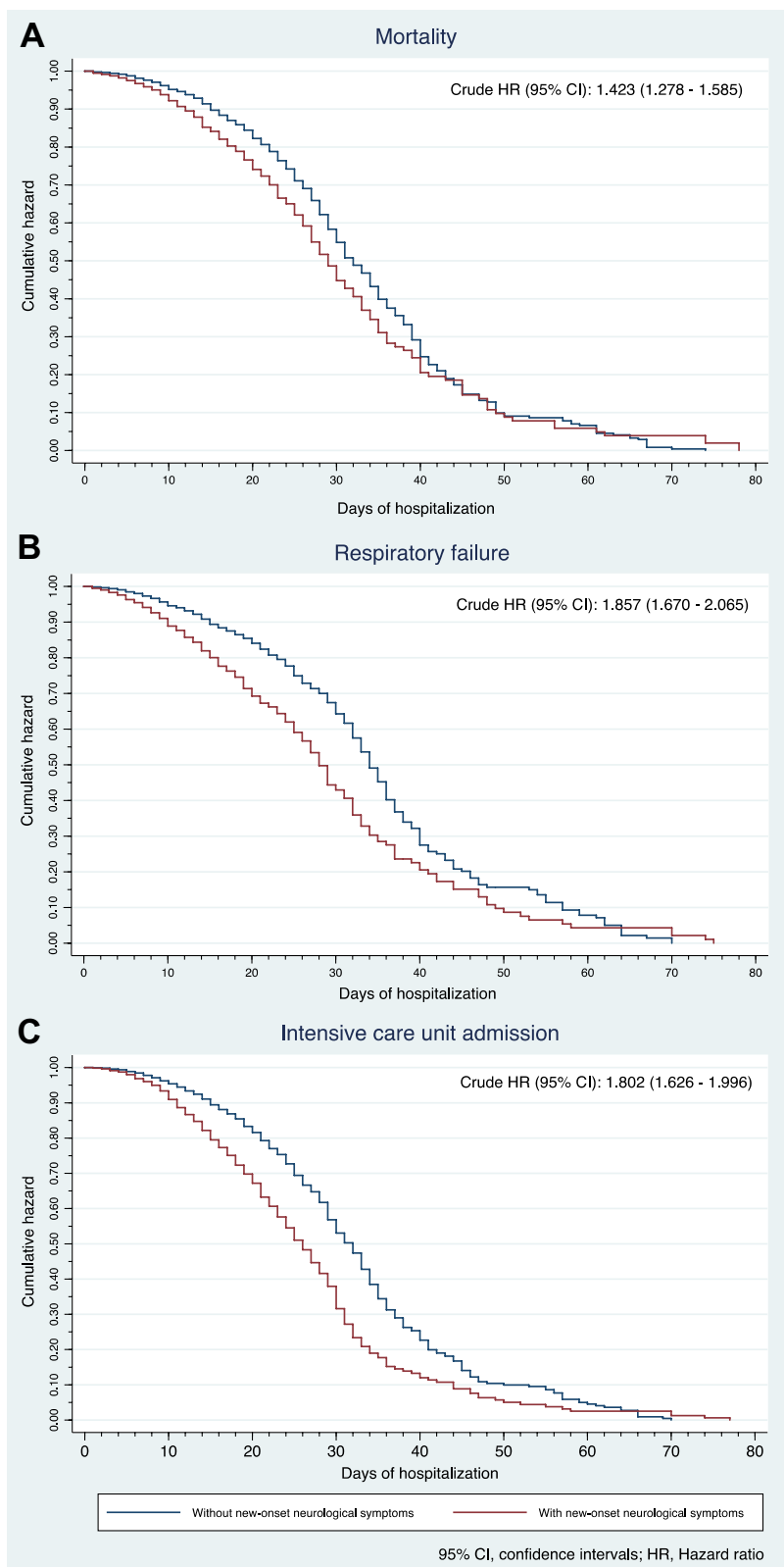

Fig. 2 Cumulative hazard by exposure to new-onset neurological symptoms for $\mathbf{A}$ mortality, $\mathbf{B}$ intensive care unit admission and $\mathbf{C}$ respiratory failure

$1.660(95 \%$ CI $1.132-2.435 ; p=0.01)$ and by $1.352(95 \%$ CI $1.042-1.752 ; p=0.023)$, respectively, in the NNS group compared to those in the non-NNS group. However, among the critical cases, the adjusted HR for mortality became nonsignificant (HR 1.043, 95\% CI 0.920-1.181; $p=0.511)$.

\section{Respiratory failure}

There were 1608 (14.8\%) patients who had respiratory failure. Pneumonia $(n=927,57.6 \%)$ and ARDS $(n=868,54 \%)$ were the most common causes of respiratory failure. Among those who had respiratory failure, a higher proportion of patients was found in the NNS compared to the non-NNS group $(p<0.001)$; among those who had a respiratory failure due to pneumonia $(p<0.001)$, ARDS $(p<0.001)$, shock $(p<0.001)$, central neurological cause $(p<0.001)$, and pulmonary edema $(p<0.001)$, a statistically higher percentage of patients was found in the NNS group. The crude HR for respiratory failure was significantly higher among those in the NNS group by 1.857 (95\% CI 1.670-2.065) than those in the non-NNS group (see Fig. 2B). After adjusting for age, sex, smoking status, and presence of HPN and DM, the risk of respiratory failure differed depending on the disease severity. Among the mild, severe, and critical cases, the adjusted HRs for respiratory failure were still significantly increased by 1.914 (95\% CI $1.346-2.722 ; p<0.001)$, by 1.614 (95\% CI $1.260-2.068 ; p<0.001)$ and by $1.234(95 \%$ CI 1.089-1.398; $p=0.001$ ), respectively, in the NNS group than those in the non-NNS group.

\section{Duration of ventilator dependence (DVD)}

Among those patients needing mechanical ventilation, the overall median DVD was 13 days (IQR 8-20). There was no significant difference in the median DVD between patients in the NNS and non-NNS groups $(p=0.612)$. The crude OR for longer DVD (i.e., $\geq 16$ days) was insignificant at 0.979 (95\% CI $0.793-1.207 ; p=0.841$ ). After adjusting for age, sex, and COVID-19 severity, the adjusted OR for longer DVD remained insignificant at 0.954 (95\% CI 0.772-1.179; $p=0.663)$.

\section{ICU admission}

A total of 1740 patients (16.0\%) from our full cohort were admitted to the ICU. ARDS ( $n=956,54.9 \%)$ and shock $(n=180,10.3 \%)$ were the most common reason for ICU admission. Among those admitted to the ICU, a higher proportion of patients was found in the NNS compared to the non-NNS group $(p<0.001)$. Similarly, a statistically higher percentage of patients was found in the NNS group among those who were admitted to the ICU due to ARDS $(p<0.001)$, shock $(p<0.001)$, impaired level of consciousness $(p<0.001)$, acute kidney injury necessitating dialysis $(p<0.001)$, treatment-related indication $(p<0.001)$, acute stroke $(p<0.001)$, and cerebral edema $(p<0.001)$. The crude HR was significantly higher among those in the NNS group by 1.857 (95\% CI 1.670-2.065) than those in the non-NNS group (see Fig. 2C). After adjusting for age, sex, smoking status, and presence of HPN and DM, the risk for ICU admission differed depending on disease severity. Among the mild and severe cases, the adjusted HRs for ICU admission were still significantly higher by 1.973 (95\% CI $1.457-2.673 ; p<0.001)$ and by 1.831 (95\% CI 1.506-2.226; 
$p<0.001$ ), respectively, in the NNS group compared to those in the non-NNS group.

\section{Length of ICU stay (LICUS)}

Among those patients admitted to the ICU, the overall median LICUS was 15 days (IQR 9.5-21). There was no significant difference in median LICUS between patients in the NNS and non-NNS groups $(p=0.887)$. The crude OR for longer LICUS (i.e., 16 days) was insignificant at 0.969 (95\% CI $0.763-1.229 ; p=0.793)$. After adjusting for age, sex, and disease severity, the adjusted OR for longer LICUS remained insignificant at 0.983 (95\% CI 0.772-1.252; $p=0.892)$.

\section{Length of hospital stay (LHS)}

Among the full cohort, the overall median LHS was 13 days (10-19). There was a significant difference in the median LHS between patients in the NNS and non-NNS groups $(p=0.002)$. The crude OR for longer LHS (i.e., $\geq 14$ days) was insignificant at 1.037 (95\% CI $0.941-1.142 ; p=0.465)$. After adjusting for age, sex, and disease severity, the adjusted OR for longer LHS remained insignificant at 1.045 (95\% CI 0.947-1.153; $p=0.378$ ).

\section{Discussion}

To the best of our knowledge, we presented the largest Philippine cohort study involving 10,881 hospitalized patients with COVID-19 infection with substantial information on their neurological characteristics. Furthermore, we investigated the effects of the presence of neurological manifestations at the onset on clinically relevant outcomes in these patients.

The incidences of at least one new-onset neurological signs/symptoms in the context of COVID-19 infection were extremely wide-ranging, i.e., $\sim 12$ to $\sim 85 \%$. The wide extent of these percentages was based on retrospective and prospective studies from various countries: Austria (Zifko et al. 2021); China (Mao et al. 2020; Xiong et al. 2020) Egypt (Khedr et al. 2021); Iran (Amanat et al. 2021; Ghaffari et al. 2021); Italy (Benussi et al. 2020; Rifino et al. 2021; Travi et al. 2021); France (Kremer et al. 2020); Germany (Fleischer et al. 2021); Mexico (Flores-Silva et al. 2021); Pakistan (Iltaf et al. 2020); Poland (Wnuk et al. 2021); Portugal (Oliveira et al. 2021); South Korea (Kim et al. 2021); Spain (García-Azorín et al. 2021a, b; García-Moncó et al. 2020; García-Azorín et al. 2021a, b; Romero-Sánchez et al. 2020); Turkey (Karadaş et al. 2020; Yuksel et al. 2021); United States of America (Chachkhiani et al. 2020; Eskandar et al. 2021; Frontera et al. 2021; Liotta et al. 2020); multinational (Chou et al. 2021). Systematic reviews with or without meta-analysis (Cagnazzo et al. 2021; Chua et al. 2020; Collantes et al. 2021; Pinzon et al. 2020; Romoli et al. 2020; Tsai et al. 2020; Vakili et al. 2021) and narrative/ scoping reviews (Ahmed et al. 2020; Maury et al. 2021; Roy et al. 2021; Shehata et al. 2021; Wenting et al. 2020; Whittaker et al. 2020; Xu et al. 2021; Yachou et al. 2020; Zubair et al. 2020) were also published. Typically described new-onset neurological manifestations of COVID-19 in the literature included anosmia/ageusia, headache, nausea, myalgia, fatigue, dizziness, acute cerebrovascular events, seizures, and altered mental status/encephalopathy. In our cohort study, we showed that approximately one in twenty COVID-19 patients (i.e., 5\%) had a new-onset headache, anosmia/hyposmia, and altered sensorium while one in eleven patients (i.e., $~ 9 \%$ ) had a new-onset neurological disorder. The most common complications were encephalopathy, stroke and seizure events. It is unknown and difficult to determine if the considerable variations in the percentages of neurological manifestations among the studies are due to differences in the susceptibility among the diverse populations or the neuroinvasive potentials of certain COVID-19 variants. However, we theorize that the varying definitions or ascertainment of neurological manifestations, method of data collection, recording/recall bias, sampling error and other biased played a much larger role in these differences.

Among the full cohort in our study, a substantial number experienced respiratory failure (14.8\%), were admitted to the ICU (16.0\%) and died (15.6\%). Of particular concern was that the new-onset neurological symptoms (NNS) in COVID-19 patients significantly increase the risk of poor outcomes such as mortality, respiratory failure and ICU admission compared to those patients without NNS. On the other hand, the presence of NNS was not significantly associated with a longer length of mechanical ventilation, ICU stay, and hospital admission.

Our data showed that the crude HR of mortality in COVID-19 patients with NNS was increased by $42 \%$ over those without NNS. With adjustments for confounders and taking into account the disease severity, mortality risk is significantly higher by $66 \%$ among mild cases and by $35 \%$ among severe cases. Among critically ill individuals, the presence of NNS may seem to be irrelevant to mortality. We believe that other probable, more fundamental factors may be operating as disease severity progresses such as cardiopulmonary and metabolic complications. Compared to the other matched case-control study with 2324 COVID-19 patients done in NYC, the odds of death was significantly increased by $27 \%$ in those with neurological manifestations than those without (Eskandar et al. 2021). A large cohort study also conducted in NYC with 4491 COVID-19 patients showed a significant increase in HR by $38 \%$ after adjusting for significant confounders, which was comparable to our own estimates (Frontera et al. 2021). 
In contrast to these studies, our cohort demonstrated that the proportions of COVID-19 patients with NNS who died due to ARDS, septic shock, multi-organ dysfunction syndrome, and brain herniation were significantly higher compared to those without NNS.

It may be intuitive to suspect that a city with a high population density like NYC would yield worse outcomes particularly in patients with COVID-19; however, other underlying factors may be operative particularly in our country where the healthcare system is at higher risk of being overwhelmed (COVID-19): an ongoing public health crisis in the Philippines 2021). In 2018, there were 23 beds per 10,000 individuals in the National Capital Region while the rest of Luzon, Visayas, and Mindanao had only 8.2, 7.8, and 8.3 beds, respectively (Dayrit et al. 2018). The increase in the role of the private sector in healthcare service delivery induces reliance on out-of-pocket healthcare expenses. In 2018 , a total of $\sim 54 \%$ and $\sim 12 \%$ is supplied by out-of-pocket payment and voluntary health care payment methods, respectively, to the health expenditure financing scheme (Ignacio et al. 2020; Mapa 2019). The deficient medical infrastructure, insufficient healthcare workforce, and the inadequate government action on contact tracing, mass testing, and vaccine rollout remains to be a major problem that may lead to poor outcomes for our patients infected with COVID-19 (COVID-19): an ongoing public health crisis in the Philippines 2021).

In our cohort, we also provided initial and relatively precise proof that NNS in COVID-19 infection significantly increases the HR of developing respiratory failure with significantly different magnitudes of effect in terms of disease severity after fully adjusting for factors; $91 \%, 61 \%$ and $23 \%$ in mild, severe, and critical cases, respectively. In addition, our data showed that apart from pneumonia, ARDS, shock and pulmonary edema, a significantly higher proportion of COVID-19 patients with NNS had respiratory failure attributed to central neurological causes compared to those in the non-NNS group. These support clinical evidence on the hypothesis that SARS-CoV-2 may infect the medullary cardiorespiratory centers via the peripheral nerve terminals (e.g., baro- and chemoreceptors) in the pulmonary system through synapse-connected routes ( $\mathrm{Li}$ et al. 2020; Machado-Curbelo 2020). Histopathological studies of several brain specimens demonstrated evidence of viral infiltration or encephalitic characteristics with neuronal cell loss and axonal degeneration affecting brainstem nuclei and tracts without documented infarction (Jaunmuktane et al. 2020; Younger 2021). In a recent comprehensive systematic review of neuropathologic findings in COVID-19 patients, other possible mechanisms that can potentially contribute to damage in cardiorespiratory centers in the brainstem leading to respiratory failure in COVID-19 infection may involve hypoxic/ischemic changes or territorial infarctions, microglial/astrocytic activation, and reactive gliosis (Pajo et al. 2021).

Furthermore, our study was able to shed light on relevant evidence relating NNS and ICU admission in general. In particular, there was a significantly increased risk (i.e., added $80 \%$ risk) for ICU admission in COVID-19 patients with NNS compared to those without NNS. Similar to mortality and respiratory failure outcomes, disease severity was found to be a significant effect modifier for ICU admission; $97 \%$ and $83 \%$ increased risk in mild and severe cases, respectively. These data suggest that NNS may potentially predict increased utilization of ICU/ICU-comparable settings that may lead to elevated healthcare costs among patients with COVID-19 patients. In addition, our data showed that there were significantly higher percentages of patients in the NNS cohort admitted due to ARDS, shock, impaired level of consciousness, acute kidney injury necessitating dialysis, acute stroke, and cerebral edema compared to those in the non-NNS.

Indeed, most previously published reports were focused on the characterization of NNS in COVID-19. Compared to these precursory studies, our study imparted valuable information from a much larger sample size of COVID-19 patients which provides an advantage of limiting sampling error and allows more precise estimates of the associations. To extend the comprehensiveness of our report, the findings in the neuroimaging and CSF were also provided. Although a number of previous studies provided some insights on the association of neurological manifestations to in-hospital mortality, our study provided new information on the relationship of NNS to specific causes of mortality, to the incidence of respiratory failure and its specific causes, to the need for admission to the ICU and the particular reasons for the admission. Furthermore, our study also revealed data on the associations of NNS with a longer duration of ventilator dependence, a longer length of ICU stay, and longer hospital stay. At present, the relationships between NNS and these other outcomes are insufficiently described in the literature. These outcomes can be also considered clinically useful particularly to estimate the magnitude of the risk of having certain poor outcomes when a COVID-19 patient had NNS compared to those without NNS.

Our study has inherent limitations. The data reflected exposures and outcomes of hospitalized COVID-19 patients; thus, information from patients who were not admitted was not captured by our estimates. Moreover, because only admitted patients were involved in this study, mortality and respiratory failure are expected to be overestimated since substantially more severe and critical COVID-19 patients are admitted to the hospital. There may be certain periods during the collection of data when our healthcare system was overwhelmed. Hence, the availability to admit patients to the hospital or to the ICU as well as the capacity to sufficiently 
document clinical/neurological features and outcomes of patients by our local admitting neurologists/physicians could have affected our estimated exposures/outcomes. In this cohort study, the comparison in the neurological features and outcomes of patients admitted in the urban and rural hospital setting is not feasible because all the included study sites were located in the urban setting. Other study limitations were non-documentation of their psychiatric symptoms and the treatments employed for their neurological symptoms. Recording bias was intrinsic to this study which could have contributed to underreporting of data. Nevertheless, we were able to obtain large amounts of data from the total enumeration of COVID-19 patients from 37 hospital sites located in various regions of our country. We further theorize that prospective collection of data may probably increase the effect estimates of NNS on mortality, respiratory failure, and ICU admission and may facilitate detection of other relevant confounding variables and effect modifiers affecting their relationship.

Our current study encompassed patients admitted from February to December 2020 only. It may be worthwhile to look into the differences in the neurological features of COVID-19 in 2020 compared to 2021 given the emergence of COVID-19 variants and the effects of vaccination. Previous observational studies, including our current study, provided compelling evidence of the involvement of the nervous system particularly the central nervous system (CNS). Beyond the clinical symptomatology, subsequent studies may focus on the viral staging pathology of the brain as well as documenting neuronal-glial changes in patients with COVID-19-infected CNS regions (Riederer and ter Meulen 2020). Long-term sequelae of previously affected brains by the COVID-19 that could potentially promote or precipitate certain neurodegenerative disorders must be evaluated in future clinical and brain coronavirus-related research (Riederer and ter Meulen 2020).

Acknowledgements The authors would like to thank the Philippine Neurological Association and the Expanded Hospital Research Office of the University of the Philippines- Philippine General Hospital for funding this research. The Philippine CORONA Study Group Investigators: Asian Hospital and Medical Center, Muntinlupa City (Corina Maria Socorro A. Macalintal, MD; Joanne B. Robles, MD), Baguio General Hospital and Medical Center, Baguio City (Paulo L. Cataniag, MD; Manolo Kristoffer C. Flores, MD, MBA), Cagayan Valley Medical Center, Tuguegarao City (Noreen Jhoanna C. TangcuangcoTrinidad, MD), Capitol Medical Center, Quezon City (Dan Neftalie A. Juangco, MD; Giuliani Renz G. Paas, MD), Cardinal Santos Medical Center, San Juan City (Audrey Marie U. Chua, MD, Valmarie S. Estrada, MD, Philip Rico P. Mejia, MD, Therese Franz B. Reyes, MD), Chong Hua Hospital, Cebu City (Maria Teresa A. Cañete, MD; Ferdinand Renfred A. Zapata, MD), De La Salle University Medical and Health Sciences Institute, Dasmariñas City, (Franko Eugenio B. Castillo, MD; Romulo U. Esagunde, MD; Jean B. Gantioque, MD), Dr. Jose N. Rodriguez Memorial and Sanitarium Hospital, Caloocan City (Maritoni C. Abbariao, MD; Geramie M. Acebuque, MD), Dr. Pablo O. Torre Memorial Hospital, Bacolod City (Evram V. Corral, MD), East
Avenue Medical Center, Quezon City (Marian Irene C. Escasura, MD; Marissa T. Ong, MD), Institute of Dementia Care Asia, Quezon City (Krizelle Cleo Fowler), Jose B. Lingad Memorial Regional Hospital, City of San Fernando (Arnold Angelo M. Pineda, MD; Khasmeen D. Aradani, MD), Jose R. Reyes Memorial Medical Center, Manila (Joseree-Ann S. Catindig, MD; Mark Timothy T. Cinco, MD; Mark Erving H. Ramos, MD), Lung Center of the Philippines, Quezon City (Romulus Emmanuel H. Cruz, MD; Marita B. Dantes, MD; Norberto A. Francisco, MD; Rosalia A. Teleg, MD), Makati Medical Center, Makati City (Krisverlyn B. Bellosillo, MD; Jean Paolo M. Delfino, MD; Cid Czarina E. Diesta, MD; Rosalina B. Espiritu-Picar, MD; Julie Anne V. Gamboa, MD; Cara Camille M. Matute, MD; Franzelle P. Padilla, MD; John Joshua Q. Punsalan, MD), Manila Doctors Hospital, Manila (Ma. Epifania V. Collantes, MD; Charmaine B. Que, MD; Hanifa A. Sampao, MD; Maxine Camela S. Sta. Maria, MD), Medical Center Manila, Manila (Marita M. Fuentes, MD; Jennifer Justice F. Manzano, MD; Rizza J. Umali, MD), New Era General Hospital, Quezon City (Marc Conrad C. Molina, MD), Northern Mindanao Medical Center, Cagayan de Oro City (Hazel Claire Minerva-Ang, MD; Arturo F. Surdilla, MD; Loreto P. Talabucon Jr., MD; Natasha F. Wabe, MD), Quirino Memorial Medical Center, Quezon City (Maria Victoria G. Manuel, MD; Al Inde John A. Pajantoy, MD; Josephine Cecilia V. Roque, MD; Paul Emmanuel L. Yambao, MD), Ospital ng Makati, Makati City (Christian Paul B. Banday, MD; Chritopher C. Cipriano, MD; Nehar A. Pangandaman, MD; Avery Gail C. Wasil, MD), Perpetual Succour Hospital, Cebu City (Elrey P. Inocian, MD; Jarungchai Anton S. Vatanagul, MD), Philippine General Hospital, Manila (Almira Doreen Abigail O. Apor, MD; Carissa Paz C. Dioquino, MD), Philippine Heart Center, Quezon City (Prinz Andrew M. Dela Cruz, MD; Maricar P. Yumul, MD) Research Institute for Tropical Medicine, Muntinlupa City (Ma. Alma E. Carandang-Concepcion, MD), San Juan De Dios Educational Foundation Inc.- Hospital, Pasay City (Ma. Caridad V. Desquitado, MD; Carl Kevin L. Julao, MD), San Lazaro Hospital, Manila (Dante P. Bornales, MD), Southern Isabela Medical Center, Santiago City (Generaldo D. Maylem, MD; Mark Joseph F. Cuntapay, MD), Southern Philippines Medical Center, Davao City (Annabelle Y. LaoReyes, MD; Aileen Mae B. Lee, MD; Nadia O. Manlegro, MD; Dave Mar L. Pelere, MD) St. Luke's Medical Center-Global City, Taguig City (Lina C. Laxamana, MD; Diana-Lynn S. Que, MD; Jeryl Ritzi T. Yu, MD), St. Luke's Medical Center, Quezon City (Ma. Socorro C. Martinez, MD; Alexandria E. Matic, MD; John Angelo Luigi S. Perez, MD), The Medical City, Pasig City (Glenn Anthony A. Constantino, MD; Aldanica R. Olano, MD; Liz Edenberg P. Quiles, MD; Artemio A. Roxas, Jr., MD; Jo Ann R. Soliven, MD; Michael Dorothy Frances Montojo-Tamayo, MD), University of Santo Tomas Hospital, Manila (Ma. Lourdes C. Joson, MD; Jojo R. Evangelista, MD), University of the East Ramon Magsaysay Memorial Medical Center Inc., Quezon City (Ma. Clarissa B. Nuñez, MD; Marietta C. Olaivar, MD; Dominique Q. Perez, MD), Veterans Memorial Medical Center, Quezon City (Mark Deneb O. Armeña, MD; Robert A. Barja, MD), Vicente Sotto Memorial Medical Center, Cebu City (Joshua Emmanuel E. Abejero, MD; Maritzie R. Eribal, MD), Western Visayas Medical Center, Iloilo City (Ryndell G. Alava, MD), Zamboanga City Medical Center, Zamboanga City (Muktader A. Kalbi, MD; Nasheera W. Radja, MD; Mohammad Elshad S. Sali, MD).

Author contributions AIE: conceptualization (lead); data curation (lead); formal analysis (lead); investigation (lead); methodology (lead); project administration (lead); software (lead); supervision (lead); validation (lead); visualization (lead); writing-original draft (lead); writing-review and editing (lead). MCCS: conceptualization (lead); data curation (lead); formal analysis (equal); investigation (equal); methodology (equal); project administration (lead); supervision (lead); validation (equal); writing-original draft (lead); writing-review and editing (lead). VMMA: conceptualization (lead); data curation (equal); formal 
analysis (equal); funding acquisition (lead); investigation (equal); methodology (equal); project administration (equal); resources (lead); supervision (lead); validation (equal); writing-original draft (equal); writing-review and editing (equal). RDGJ: conceptualization (lead); data curation (equal); formal analysis (equal); funding acquisition (lead); investigation (equal); methodology (equal); project administration (equal); resources (lead); supervision (lead); validation (equal); writing-original draft (equal); writing-review and editing (equal). Philippine CORONA Study Group Investigators: conceptualization, data acquisition, data curation, and writing — review and editing.

Funding (1) Philippine Neurological Association, Room 1006, Rear Tower Cathedral Height Building Complex, St. Luke's Medical Center, E. Rodriguez Avenue, Manila, Philippines (Grant number: not applicable); and (2) Expanded Hospital Research Office, University of the Philippines- Philippine General Hospital, Taft Avenue, Manila, Philippines (Grant number: not applicable). Our funding sources were not involved in the design of the protocol, study execution, analysis and interpretation of data, writing and editing of the contents of the manuscript, and in the publication of this article.

Availability of data and material Anonymized data not published within this article will be made available by request from any qualified investigator.

Code availability Not applicable.

\section{Declarations}

Conflict of interest All authors have stated explicitly that there are no conflicts of interest in connection with this article.

Ethical approval Our protocol was approved and endorsed by the local institutional review boards (code): Asian Hospital and Medical Center, Muntinlupa City (2020- 010-A); Baguio General Hospital and Medical Center (BGHMC), Baguio City (BGHMC-ERC-2020-13); Cagayan Valley Medical Center (CVMC), Tuguegarao City; Capitol Medical Center, Quezon City; Cardinal Santos Medical Center (CSMC), San Juan City (CSMC REC 2020-020); Chong Hua Hospital, Cebu City (IRB 2420-04); De La Salle Medical and Health Sciences Institute (DLSMHSI), Cavite (2020-23-02-A); East Avenue Medical Center (EAMC), Quezon City (EAMC IERB 2020- 38); Jose R. Reyes Memorial Medical Center, Manila; Jose B. Lingad Memorial Regional Hospital, City of San Fernando, Pampanga; Dr. Jose N. Rodriguez Memorial and Sanitarium Hospital, Caloocan City; Lung Center of the Philippines (LCP), Quezon City (LCP-CT-010-2020); Manila Doctors Hospital, Manila (MDH IRB 2020-006); Makati Medical Center, Makati City (MMC IRB 2020-054); Medical Center Manila, Manila (MMERC 2020-09); Northern Mindanao Medical Center, Cagayan de Oro City (025-2020); Quirino Memorial Medical Center (QMMC), Quezon City (QMMC REB GCS 2020-28); Ospital ng Makati, Makati City; University of the Philippines - Philippine General Hospital (UP-PGH), Manila (2020-314-01 SJREB); Philippine Heart Center, Quezon City; Research Institute for Tropical Medicine, Muntinlupa City (RITM IRB 2020-16); San Lazaro Hospital, Manila; San Juan De Dios Educational Foundation Inc - Hospital, Pasay City (SJRIB 2020-0006); Single Joint Research Ethics Board of the DOH, Philippines (SJREB-2020-24); Southern Isabela Medical Center, Santiago City (2020-03); Southern Philippines Medical Center (SPMC), Davao City (P20062001); St. Luke's Medical Center, Quezon City (SL20116); St. Luke's Medical Center, Bonifacio Global City, Taguig City (SL-20116); Southern Philippines Medical Center, Davao City; The Medical City, Pasig City; University of Santo Tomas Hospital, Manila (UST-REC-2020-04-071-MD); University of the East Ramon Magsay- say Memorial Medical Center, Inc, Quezon City (0835/E/2020/063); Veterans Memorial Medical Center (VMMC), Quezon City (VMMC2020-025) and Vicente Sotto Memorial Medical Center, Cebu City (VSMMC-REC-O-2020-048).

Consent to participant Acquiring informed consent was not needed for this study since the design was a retrospective cohort study employing medical chart review and the data obtained for this study were completely anonymized.

Consent for publication We, the authors, consent to publish our manuscript entitled "COVID-19 Outcomes of 10,881 patients: Retrospective study of Neurological symptoms and Associated manifestations (Philippine CORONA Study)" in the Journal of Neural Transmission. This manuscript has never been published in part nor concurrently submitted elsewhere. The authors have seen and approved the manuscript, and significantly contributed to the work.

Technical review Our protocol underwent technical review from the following institutions: Department of Neurosciences, Philippine General Hospital and College of Medicine, University of the Philippines Manila, from the Cardinal Santos Medical Center, San Juan City, and from the Research Center for Clinical Epidemiology and Biostatistics, De La Salle Medical and Health Sciences Institute, Dasmariñas City, Cavite.

Protocol registration and publication Our protocol was registered at the ClinicalTrials.gov website (NCT04386083). The full protocol was published by the British Medical Journal (BMJ) Open (see the following article: Espiritu AI, Sy MCC, Anlacan VMM, Jamora RDG. The Philippine COVID-19 Outcomes: a Retrospective study Of Neurological manifestations and Associated symptoms (The Philippine CORONA study): a protocol study. BMJ Open 2020; 10:e040944. Available at: https://bmjopen.bmj.com/lookup/doi/10.1136/bmjopen2020-040944.

List of study sites Asian Hospital and Medical Center, Muntinlupa City; Baguio General Hospital and Medical Center, Baguio City; Cagayan Valley Medical Center, Tuguegarao City; Capitol Medical Center, Quezon City; Cardinal Santos Medical Center, San Juan City; Chong Hua Hospital, Cebu City; De La Salle University Medical and Health Sciences Institute, Dasmariñas City; East Avenue Medical Center, Quezon City; Jose B. Lingad Memorial Regional Hospital, City of San Fernando, Pampanga; Dr. Jose N. Rodriguez Memorial and Sanitarium Hospital, Caloocan City; Jose R. Reyes Memorial Medical Center, Manila; Lung Center of the Philippines, Quezon City; Manila Doctors Hospital, Manila; Medical Center Manila, Manila; Makati Medical Center, Makati City; New Era General Hospital, Quezon City; Northern Mindanao Medical Center, Cagayan de Oro City; Quirino Memorial Medical Center, Quezon City; Ospital ng Makati, Makati City; Perpetual Succour Hospital, Cebu City; Dr. Pablo O. Torre Memorial Hospital (Riverside Medical Center, Inc.), Bacolod City; University of the Philippines-Philippine General Hospital, Manila; Philippine Heart Center, Quezon City; Research Institute for Tropical Medicine, Muntinlupa City; San Lazaro Hospital, Manila; San Juan De Dios Educational Foundation Inc.-Hospital, Pasay City; Southern Isabela Medical Center, Santiago City; St. Luke's Medical Center, Quezon City; St. Luke's Medical Center, Bonifacio Global City, Taguig City; Southern Philippines Medical Center, Davao City; The Medical City, Pasig City; University of the East Ramon Magsaysay Memorial Medical Center, Inc., Quezon City; University of Santo Tomas Hospital, Manila; Veterans Memorial Medical Center, Quezon City; Vicente Sotto Memorial Medical Center, Cebu City; Western Visayas Medical Center, Iloilo City; Zamboanga City Medical Center, Zamboanga City. 
Open Access This article is licensed under a Creative Commons Attribution 4.0 International License, which permits use, sharing, adaptation, distribution and reproduction in any medium or format, as long as you give appropriate credit to the original author(s) and the source, provide a link to the Creative Commons licence, and indicate if changes were made. The images or other third party material in this article are included in the article's Creative Commons licence, unless indicated otherwise in a credit line to the material. If material is not included in the article's Creative Commons licence and your intended use is not permitted by statutory regulation or exceeds the permitted use, you will need to obtain permission directly from the copyright holder. To view a copy of this licence, visit http://creativecommons.org/licenses/by/4.0/.

\section{References}

Ahmed MU, Hanif M, Ali MJ, Haider MA, Kherani D, Memon GM, Karim AH, Sattar A (2020) Neurological manifestations of COVID-19 (SARS-CoV-2): a review. Front Neurol 11:518. https://doi.org/10.3389/fneur.2020.00518

Amanat M, Rezaei N, Roozbeh M, Shojaei M, Tafakhori A, Zoghi A, Darazam IA, Salehi M, Karimialavijeh E, Lima BS, Garakani A, Vaccaro A, Ramezani M (2021) Neurological manifestations as the predictors of severity and mortality in hospitalized individuals with COVID-19: a multicenter prospective clinical study. BMC Neurol 21:116. https://doi.org/10.1186/ s12883-021-02152-5

Anderson RM, Vegvari C, Truscott J, Collyer BS (2020) Challenges in creating herd immunity to SARS-CoV-2 infection by mass vaccination. Lancet 396:1614-1616. https://doi.org/10.1016/ S0140-6736(20)32318-7

Benussi A, Pilotto A, Premi E, Libri I, Giunta M, Agosti C, Alberici A, Baldelli E, Benini M, Bonacina S, Brambilla L, Caratozzolo S, Cortinovis M, Costa A, Cotti Piccinelli S, Cottini E, Cristillo V, Delrio I, Filosto M, Gamba M, Gazzina S, Gilberti N, Gipponi $\mathrm{S}$, Imarisio A, Invernizzi P, Leggio U, Leonardi M, Liberini P, Locatelli M, Masciocchi S, Poli L, Rao R, Risi B, Rozzini L, Scalvini A, Schiano di Cola F, Spezi R, Vergani V, Volonghi I, Zoppi N, Borroni B, Magoni M, Pezzini A, Padovani A (2020) Clinical characteristics and outcomes of inpatients with neurologic disease and COVID-19 in Brescia, Lombardy, Italy. Neurology 95:e910 e920. https://doi.org/10.1212/WNL.0000000000009848

Cagnazzo F, Arquizan C, Derraz I, Dargazanli C, Lefevre P-H, Riquelme C, Gaillard N, Mourand I, Gascou G, Bonafe A, Costalat V (2021) Neurological manifestations of patients infected with the SARS-CoV-2: a systematic review of the literature. J Neurol 268:2656-2665. https://doi.org/10.1007/s00415-020-10285-9

Chachkhiani D, Soliman MY, Barua D, Isakadze M, Villemarette-Pittman NR, Devier DJ, Lovera JF (2020) Neurological complications in a predominantly African American sample of COVID-19 predict worse outcomes during hospitalization. Clin Neurol Neurosurg 197:106173. https://doi.org/10.1016/j.clineuro.2020.106173

Chou SH-Y, Beghi E, Helbok R, Moro E, Sampson J, Altamirano V, Mainali S, Bassetti C, Suarez JI, McNett M, Nolan L, Temro K, Cervantes-Arslanian AM, Anand P, Mukerji S, Alabasi H, Westover MB, Kavi T, John S, Da Silva I, Shaik A, Sarwal A, Izzy S, Liotta EM, Batra A, Aysenne A, Rubinos C, Azzam AY, Azab MA, Sandall J, Persondek LM, Ulmer H, Rass V, Pfausler B, Müller C, Jung S, Crean M, Meoni S, Bereczki D, Kovács T, Agajany N, Armon C, Wolfson S, Cotelli MS, Bianchi E, Riahi A, Öztürk S, Ural O, Viktoriia G, Lesiv M, Maia L, Oliveira V, Seabra M, Carvalho V, Vespa P, Provencio J, Olson D, Hemphill C, Venkatasubba Rao CP, Ko N, Fink E, Robertson C, Schober M, Smith Scott A, Hammond M, Paul N, Safonova A, Kaplan L, Ratnayake C, Sharma AD, Skeel A, Villamizar Rosales C, Dolak D, Varelas
P, Lotman L, Kaltenbach L, David KM (2021) Global incidence of neurological manifestations among patients hospitalized with COVID-19 - a report for the GCS-NeuroCOVID Consortium and the ENERGY Consortium. JAMA Netw Open 4:e2112131. https://doi.org/10.1001/jamanetworkopen.2021.12131

Chua TH, Xu Z, King NKK (2020) Neurological manifestations in COVID-19: a systematic review and meta-analysis. Brain Inj 34:1549-1568. https://doi.org/10.1080/02699052.2020.1831606

Chuang DT, Aydemir S, Magda P, Thomas C, Zarnegar R (2021) Neurological manifestations as primary presentation of COVID19 in hospitalized patients. Acta Neurol Scand 143:569-574. https://doi.org/10.1111/ane.13399

Collantes MEV, Espiritu AI, Sy MCC, Anlacan VMM, Jamora RDG (2021) Neurological manifestations in COVID-19 infection: a systematic review and meta-analysis. Can J Neurol Sci 48:6676. https://doi.org/10.1017/cjn.2020.146

Coronavirus (COVID-19) Vaccinations Statistics and Research - Our World in Data [WWW Document] (2021) https://ourworldin data.org/covid-vaccinations?country=OWID_WRL. Accessed 7.24.21

Coronavirus disease (COVID-19) [WWW Document], n.d. URL https://www.who.int/emergencies/diseases/novel-coronavirus2019?gclid=CjwKCAjwj6SEBhAOEiwAvFRuKBjhCUq50rg eS4N2ae9isWOnO9stb9iIL53Vmf7PGq9JIOy5LHadEBoC UwkQAvD_BwE. Accessed 4.30.21

COVID-19: an ongoing public health crisis in the Philippines, 2021. Lancet Reg. Heal. - West. Pacific 9, 100160. https://doi.org/10. 1016/j.lanwpc.2021.100160

Dayrit M, Lagrada L, Picazo O, Pons M, Villaverde M (2018) The Philippines health system review. World Health Organization, Regional Office for SouthEast Asia, New Delhi

Department of Health (Philippines) [WWW Document] (2021). https://doh.gov.ph/2019-nCoV. Accessed 7.24.21b

Department of Health (Philippines) n.d. Government further intensifying COVID-19 response with local transmission of delta variant [WWW Document]. URL https://doh.gov.ph/press-release/ DOH-GOVERNMENT-FURTHER-INTENSIFYING-COVID19-RESPONSE-WITH-LOCAL-TRANSMISSION-OF-DELTAVARIANT. Accessed 7.24.21a

Eskandar EN, Altschul DJ, de la Garza Ramos R, Cezayirli P, Unda SR, Benton J, Dardick J, Toma A, Patel N, Malaviya A, Flomenbaum D, Fernandez-Torres J, Lu J, Holland R, Burchi E, Zampolin R, Hsu K, McClelland A, Burns J, Erdfarb A, Malhotra R, Gong M, Semczuk P, Gursky J, Ferastraoaru V, Rosengard J, Antoniello D, Labovitz D, Esenwa C, Milstein M, Boro A, Mehler MF (2021) Neurologic syndromes predict higher inhospital mortality in COVID-19. Neurology 96:e1527-e1538. https://doi.org/10.1212/WNL.0000000000011356

Espiritu AI, Sy MCC, Anlacan VMM, Jamora RDG (2020) The Philippine COVID-19 Outcomes: a retrospective study of neurological manifestations and associated symptoms (The Philippine CORONA study): a protocol study. BMJ Open 10:e040944. https://doi.org/10.1136/bmjopen-2020-040944

Fleischer M, Köhrmann M, Dolff S, Szepanowski F, Schmidt K, Herbstreit F, Güngör C, Stolte B, Steiner KM, Stadtler C, Riße J, Fiedler M, Meyerzu Hörste G, Mausberg A-K, Kill C, Forsting M, Sure U, Dittmer U, Witzke O, Brenner T, Kleinschnitz C, Stettner M (2021) Observational cohort study of neurological involvement among patients with SARS-CoV-2 infection. Ther Adv Neurol Disord. https://doi.org/10.1177/1756286421993701

Flores-Silva FD, García-Grimshaw M, Valdés-Ferrer SI, ViguerasHernández AP, Domínguez-Moreno R, Tristán-Samaniego DP, Michel-Chávez A, González-Duarte A, Vega-Boada FA, Reyes-Melo I, Jiménez-Ruiz A, Chávez-Martínez OA, Rebolledo-García D, Marché-Fernández OA, Sánchez-Torres S, García-Ramos G, Cantú-Brito C, Chiquete E (2021) Neurologic 
manifestations in hospitalized patients with COVID-19 in Mexico City. PLoS ONE 16:e0247433. https://doi.org/10.1371/journ al.pone. 0247433

Frontera JA, Sabadia S, Lalchan R, Fang T, Flusty B, Millar-Vernetti P, Snyder T, Berger S, Yang D, Granger A, Morgan N, Patel P, Gutman J, Melmed K, Agarwal S, Bokhari M, Andino A, Valdes E, Omari M, Kvernland A, Lillemoe K, Chou SHY, McNett M, Helbok R, Mainali S, Fink EL, Robertson C, Schober M, Suarez JI, Ziai W, Menon D, Friedman D, Friedman D, Holmes M, Huang J, Thawani S, Howard J, Abou-Fayssal N, Krieger P, Lewis A, Lord AS, Zhou T, Kahn DE, Czeisler BM, Torres J, Yaghi S, Ishida K, Scher E, de Havenon A, Placantonakis D, Liu M, Wisniewski T, Troxel AB, Balcer L, Galetta S (2021) A prospective study of neurologic disorders in hospitalized patients with COVID-19 in New York City. Neurology 96:e575-e586. https://doi.org/10.1212/ WNL.0000000000010979

García-Azorín D, Abildúa MJA, Aguirre MEE, Fernández SF, Moncó JCG, Guijarro-Castro C, Platas MG, Delgado FR, Andrés JML, Ezpeleta D, Fernández AC, Horga A, Prieto AB, del Villar IA, Núñez AU, Serrano ÁA, García A, Menéndez BM, Recasens BB, Serrano BS, de la Esperanza BT, de la Hoz CPFF, Juste CT, Martín CV, García CF, Ochoa M, Íñiguez C, García DM, Pérez Martínez DA, Santacruz DMC, Robert MF, Gomez EF, Puiggròs E, Álvarez EF, Llamas EP, Villareal E, Díaz EF, Burguillos FM, Beitia GA, Gutiérrez-Gutiérrez G, Monteiro GC, Ygual GC, Hernández G, Rubio G, Alonso H, Froiz IP, García IR, Peñas IR, Pérez Sánchez JR, García JT, Álvarez JV, Domínguez JF, Etessam JP, Equiza J, Pascual JM, Usieto JAO, Reyes JA, Gómez JB, Bueno JCR, Velasquez JLC, López JMB, Raquel Lamas LA, Lezama LBL, Caballero L, Davila LG, González N, de Antonio LAR, Torres MAG, Zabaleta MM, Rodríguez MM, Moragues MD, García MFV, Hernández M, Abildúa MJA, Rabasa M, Santos MR, Usero M, Zurdo M, Más M, Maneiro M, Platas MG, Muriana Nafría NG, Esteve OB, del Saz SP, Rocío Vilar Ventura RM, Atienza S, Navas SR, Fernández SF, Borja S, Navarro SG, García SK, García S, Salas TM, Palasí T, Cantero VR (2021a) Neurological presentations of COVID-19: findings from the spanish society of neurology neuro COVID-19 registry. J Neurol Sci 423:117283. https://doi.org/10.1016/j.jns.2020.117283

García-Azorín D, Trigo J, Martínez-Pías E, Hernández-Pérez I, VallePeñacoba G, Talavera B, Simón-Campo P, Lera M, ChavarríaMiranda A, López-Sanz C, Gutiérrez-Sánchez M, MartínezVelasco E, Pedraza M, Sierra Á, Gómez-Vicente B, Guerrero Á, Arenillas JF (2021b) Neurological symptoms in Covid-19 patients in the emergency department. Brain Behav 11:117283. https://doi. org/10.1002/brb3.2058

García-Moncó JC, Cabrera-Muras A, Collía-Fernández A, Erburu-Iriarte M, Rodrigo-Armenteros P, Oyarzun-Irazu I, Martínez-Condor D, Bilbao-González A, Carmona-Abellán M, Caballero-Romero I, Gómez-Beldarrain M (2020) Neurological reasons for consultation and hospitalization during the COVID-19 pandemic. Neurol Sci 41:3031-3038. https://doi.org/10.1007/s10072-020-04714-w

Ghaffari M, Ansari H, Beladimoghadam N, Aghamiri SH, Haghighi M, Nabavi M, Mansouri B, Mehrpour M, Assarzadegan F, Hesami O, Sedaghat M, Farahbakhsh M, Lima BS (2021) Neurological features and outcome in COVID-19: dementia can predict severe disease. J Neurovirol 27:86-93. https://doi.org/10.1007/ s13365-020-00918-0

Ignacio KHD, Espiritu AI, Jamora RDG (2020) The current status and challenges in multiple sclerosis management in the Philippines. Mult Scler Relat Disord 46:102510. https://doi.org/10.1016/j. msard.2020.102510

Iltaf S, Fatima M, Salman S, Salam J, Abbas S (2020) Frequency of neurological presentations of coronavirus disease in patients presenting to a tertiary care hospital during the 2019 coronavirus disease pandemic. Cureus 12:e9846. https://doi.org/10.7759/ cureus. 9846

Jaunmuktane Z, Mahadeva U, Green A, Sekhawat V, Barrett NA, Childs L, Shankar-Hari M, Thom M, Jäger HR, Brandner S (2020) Microvascular injury and hypoxic damage: emerging neuropathological signatures in COVID-19. Acta Neuropathol 140:397-400. https://doi.org/10.1007/s00401-020-02190-2

Karadaş Ö, Öztürk B, Sonkaya AR (2020) A prospective clinical study of detailed neurological manifestations in patients with COVID-19. Neurol Sci 41:1991-1995. https://doi.org/10.1007/ s10072-020-04547-7

Khedr EM, Abo-Elfetoh N, Deaf E, Hassan HM, Amin MT, Soliman RK, Attia AA, Zarzour AA, Zain M, Mohamed-Hussein A, Hashem MK, Hassany SM, Aly A, Shoyb A, Saber M (2021) Surveillance study of acute neurological manifestations among 439 Egyptian patients with COVID-19 in Assiut and Aswan university hospitals. Neuroepidemiology 55:109-118. https:// doi.org/10.1159/000513647

Kim HK, Cho YJ, Lee S-Y (2021) Neurological manifestations in patients with COVID-19: experiences from the central infectious diseases hospital in South Korea. J Clin Neurol 17:435442. https://doi.org/10.3988/jcn.2021.17.3.435

Kremer S, Lersy F, de Sèze J, Ferré J-C, Maamar A, Carsin-Nicol B, Collange O, Bonneville F, Adam G, Martin-Blondel G, Rafiq M, Geeraerts T, Delamarre L, Grand S, Krainik A, Caillard S, Marc Constans J, Metanbou S, Heintz A, Helms J, Schenck M, Lefèbvre N, Boutet C, Fabre X, Forestier G, de Beaurepaire I, Bornet G, Lacalm A, Oesterlé H, Bolognini F, Messie J, Hmeydia G, Benzakoun J, Oppenheim C, Bapst B, Megdiche I, HenriFeugeas M-C, Khalil A, Gaudemer A, Jager L, Nesser P, Talla Mba Y, Hemmert C, Feuerstein P, Sebag N, Carré S, Alleg M, Lecocq C, Schmitt E, Anxionnat R, Zhu F, Comby P-O, Ricolfi F, Thouant P, Desal H, Boulouis G, Berge J, Kazémi A, Pyatigorskaya N, Lecler A, Saleme S, Edjlali-Goujon M, Kerleroux B, Zorn P-E, Mathieu M, Baloglu S, Ardellier F-D, Willaume T, Brisset JC, Boulay C, Mutschler V, Hansmann Y, Mertes P-M, Schneider F, Fafi-Kremer S, Ohana M, Meziani F, David J-S, Meyer N, Anheim M, Cotton PF (2020) Brain MRI findings in severe COVID-19: a retrospective observational study. Radiology 297:E242-251. https://doi.org/10.1148/radiol.2020202222

Li YC, Bai WZ, Hashikawa T (2020) The neuroinvasive potential of SARS-CoV2 may play a role in the respiratory failure of COVID-19 patients. J Med Virol 92:552-555. https://doi.org/ 10.1002/jmv. 25728

Liotta EM, Batra A, Clark JR, Shlobin NA, Hoffman SC, Orban ZS, Koralnik IJ (2020) Frequent neurologic manifestations and encephalopathy-associated morbidity in Covid-19 patients. Ann Clin Trans1 Neurol 7:2221-2230. https://doi.org/10.1002/acn3. 51210

Machado-Curbelo C (2020) Severe COVID-19 cases: Is respiratory distress partially explained by central nervous system involvement? MEDICC Rev 22:38-39. https://doi.org/10.37757/ MR2020.V22.N2.10

Mao L, Jin H, Wang M, Hu Y, Chen S, He Q, Chang J, Hong C, Zhou Y, Wang D, Miao X, Li Y, Hu B (2020) Neurologic manifestations of hospitalized patients with coronavirus disease 2019 in Wuhan, China. JAMA Neurol 77:683-690. https://doi.org/10. 1001/jamaneurol.2020.1127

Mapa, C.D. (2019) Total Health Expenditures grew by 8.3 percent in 2018 [WWW Document]. 2019. URL https://psa.gov.ph/conte nt/total-health-expenditures-grew-83-percent-2018. Accessed 5.13.20

Maury A, Lyoubi A, Peiffer-Smadja N, de Broucker T, Meppiel E (2021) Neurological manifestations associated with SARSCoV-2 and other coronaviruses: a narrative review for 
clinicians. Rev Neurol (paris) 177:51-64. https://doi.org/10. 1016/j.neurol.2020.10.001

Oliveira V, Seabra M, Rodrigues R, Carvalho V, Mendes M, Pereira D, Caldeiras C, Martins B, Silva R, Azevedo A, Lima MJ, Monteiro C, Varela R, Malheiro S, Abreu M, Azevedo E, Leal Loureiro J, Tedim Cruz V, Silva MR, Magalhães R, Silva C, Maia LF, Correia M (2021) Neuro-COVID frequency and shortterm outcome in the Northern Portuguese population. Eur J Neurol. https://doi.org/10.1111/ene.14874.10.1111/ene.14874

Pajo AT, Espiritu AI, Apor ADAO, Jamora RDG (2021) Neuropathologic findings of patients with COVID-19: a systematic review. Neurol Sci 42:1255-1266. https://doi.org/10.1007/ s10072-021-05068-7

Pinzon RT, Wijaya VO, Buana RB, Al Jody A, Nunsio PN (2020) Neurologic characteristics in coronavirus disease 2019 (COVID-19): a systematic review and meta-analysis. Front Neurol 11:565. https://doi.org/10.3389/fneur.2020.00565

Riederer P, ter Meulen V (2020) Coronaviruses: a challenge of today and a call for extended human postmortem brain analyses. J Neural Transm (vienna) 127:1217-1228. https://doi.org/10.1007/ s00702-020-02230-x

Rifino N, Censori B, Agazzi E, Alimonti D, Bonito V, Camera G, Conti MZ, Foresti C, Frigeni B, Gerevini S, Grimoldi M, La Gioia S, Partziguian T, Quadri S, Riva R, Servalli MC, Sgarzi M, Storti B, Vedovello M, Venturelli E, Viganò M, Callegaro A, Arosio M, Sessa M (2021) Neurologic manifestations in 1760 COVID-19 patients admitted to Papa Giovanni XXIII Hospital, Bergamo, Italy. J Neurol 268:2331-2338. https://doi.org/10.1007/ s00415-020-10251-5

Romero-Sánchez CM, Díaz-Maroto I, Fernández-Díaz E, SánchezLarsen Á, Layos-Romero A, García-García J, González E, Redondo-Peñas I, Perona-Moratalla AB, Del Valle-Pérez JA, Gracia-Gil J, Rojas-Bartolomé L, Feria-Vilar I, Monteagudo M, Palao M, Palazón-García E, Alcahut-Rodríguez C, Sopelana-Garay D, Moreno Y, Ahmad J, Segura T (2020) Neurologic manifestations in hospitalized patients with COVID-19. Neurology 95:e1060 e1070. https://doi.org/10.1212/WNL.0000000000009937

Romoli M, Jelcic I, Bernard-Valnet R, García Azorín D, Mancinelli L, Akhvlediani T, Monaco S, Taba P, Sellner J (2020) A systematic review of neurological manifestations of SARS-CoV-2 infection: the devil is hidden in the details. Eur J Neurol 27:1712-1726. https://doi.org/10.1111/ene.14382

Roy D, Ghosh R, Dubey S, Dubey MJ, Benito-León J, Kanti Ray B (2021) Neurological and neuropsychiatric impacts of COVID-19 pandemic. Can J Neurol Sci 48:9-24. https://doi.org/10.1017/cjn. 2020.173

Shehata GA, Lord KC, Grudzinski MC, Elsayed M, Abdelnaby R, Elshabrawy HA (2021) Neurological complications of COVID19: underlying mechanisms and management. Int J Mol Sci 22:4081. https://doi.org/10.3390/ijms22084081

Travi G, Rossotti R, Merli M, D’Amico F, Chiappetta S, Giussani G, Panariello A, Corradin M, Vecchi M, Raimondi A, Baiguera C, Nocita B, Epis OM, Tarsia P, Galbiati F, Colombo F, Fumagalli R, Scaglione F, Moreno M, Percudani ME, Agostoni EC, Puoti M (2021) Neurological manifestations in patients hospitalized with COVID-19: a retrospective analysis from a large cohort in Northern Italy. Eur J Neurosci 53:2912-2922. https://doi.org/10. 1111/ejn.15159

Tsai S-T, Lu M-K, San S, Tsai C-H (2020) The neurologic manifestations of coronavirus disease 2019 pandemic: a systemic review. Front Neurol 11:498. https://doi.org/10.3389/fneur.2020.00498
Vakili K, Fathi M, Hajiesmaeili M, Salari M, Saluja D, Tafakhori A, Sayehmiri F, Rezaei-Tavirani M (2021) Neurological symptoms, comorbidities, and complications of COVID-19: a literature review and meta-analysis of observational studies. Eur Neurol. https://doi.org/10.1159/000516258

Wenting A, Gruters A, van Os Y, Verstraeten S, Valentijn S, Ponds R, de Vugt M (2020) COVID-19 neurological manifestations and underlying mechanisms: a scoping review. Front Psychiatry 11:860. https://doi.org/10.3389/fpsyt.2020.00860

Whittaker A, Anson M, Harky A (2020) Neurological manifestations of COVID-19: a systematic review and current update. Acta Neurol Scand 142:14-22. https://doi.org/10.1111/ane.13266

Wnuk M, Sawczyńska K, Kęsek T, Wrona P, Chatys-Bogacka Ż, Mazurkiewicz I, Drabik L, Jagiełła J, Szaleniec J, Czepiel J, Pawliński Ł, Bień AI, Kania M, Fiema M, Zięba-Parkitny J, Hajek A, Ucieklak D, Wilk M, Pośpiech K, Lechowicz P, Kasprzycki K, Kopka M, Hohendorff J, Katra B, Kostrzycka M, Adamczyk M, Surowiec P, Rybicka M, Walczewska J, Kamińska B, Piętak E, Bryniarski P, Marona M, Motyl M, Kępińska-Wnuk A, Włodarczyk M, Nowak K, Gradek-Kwinta E, Czyżycki M, Dwojak M, Rzemińska A, Wężyk K, Koźmiński W, Pułyk A, Garlicki A, Grodzicki T, Małecki M, Słowik A (2021) Neurological symptoms in hospitalised patients with COVID-19 and their association with in-hospital mortality. Neurol Neurochir Pol 55:314-321. https://doi.org/10.5603/PJNNS.a2021.0039

Xiong W, Mu J, Guo J, Lu L, Liu D, Luo J, Li N, Liu J, Yang D, Gao H, Zhang Y, Lin M, Shen S, Zhang H, Chen L, Wang G, Luo F, Li W, Chen S, He L, Sander JW, Zhou D (2020) New onset neurologic events in people with COVID-19 in 3 regions in China. Neurology 95:e1479-e1487. https://doi.org/10.1212/WNL.00000 00000010034

Xu Y, Zhuang Y, Kang L (2021) A review of neurological involvement in patients with SARS-CoV-2 infection. Med Sci Monit 27:e93962. https://doi.org/10.12659/MSM.932962

Yachou Y, El Idrissi A, Belapasov V, Ait Benali S (2020) Neuroinvasion, neurotropic, and neuroinflammatory events of SARS-CoV-2: Understanding the neurological manifestations in COVID-19 patients. Neurol Sci 41:2657-2669. https://doi.org/10.1007/ s10072-020-04575-3

Younger DS (2021) Postmortem neuropathology in Covid-19. Brain Pathol 31:385-386. https://doi.org/10.1111/bpa.12915

Yuksel H, Gursoy GT, Dirik EB, Kenar SG, Bektas H, Yamanel L, Guner HR (2021) Neurological manifestations of COVID-19 in confirmed and probable cases: a descriptive study from a large tertiary care center. J Clin Neurosci 86:97-102. https://doi.org/ 10.1016/j.jocn.2021.01.002

Zifko U, Schmiedlechner T, Saelens J, Zifko K, Wagner M, Assadian O, Grisold W, Stingl H (2021) Covid-19: Involvement of the nervous system. Identifying neurological predictors defining the course of the disease. J Neurol Sci 425:117438. https://doi.org/ 10.1016/j.jns.2021.117438

Zubair AS, McAlpine LS, Gardin T, Farhadian S, Kuruvilla DE, Spudich S (2020) Neuropathogenesis and neurologic manifestations of the coronaviruses in the age of coronavirus disease 2019. JAMA Neurol 77:1018. https://doi.org/10.1001/jamaneurol.2020.2065

Publisher's Note Springer Nature remains neutral with regard to jurisdictional claims in published maps and institutional affiliations. 